Accepted refereed manuscript of:

Smedley MA, Clokie BGJ, Migaud H, Campbell P, Walton J, Hunter D, Corrigan D \& Taylor J (2016) Dietary phosphorous and protein supplementation enhances seawater growth and reduces severity of vertebral malformation in triploid Atlantic salmon (Salmo salar L.),Aquaculture, 451, pp. 357-368.

DOI: $10.1016 /$ j.aquaculture.2015.10.001

(C) 2015, Elsevier. Licensed under the Creative Commons AttributionNonCommercial-NoDerivatives 4.0 International

http://creativecommons.org/licenses/by-nc-nd/4.0/ 
Elsevier Editorial System(tm) for Aquaculture

Manuscript Draft

Manuscript Number:

Title: NUTRIENT SUPPLEMENTATION ENHANCES SEAWATER GROWTH AND REDUCES SEVERITY OF VERTEBRAL MALFORMATION IN TRIPLOID ATLANTIC SALMON (Salmo salar L.)

Article Type: Research Paper

Keywords: Triploid; Salmon; Phosphorous; Nutrition; Deformity

Corresponding Author: Dr. John Taylor, PhD

Corresponding Author's Institution: University of Stirling

First Author: Marie A Smedley

Order of Authors: Marie A Smedley; Benjamin G Clokie; Herve Migaud, PhD; Patrick Campbell, PhD; Jamie Walton, MSc; Dougie Hunter; David Corrigan; John Taylor, PhD

Abstract: Diploid (2N) and triploid (3N) sibling post-smolts were divided between six sea pens and fed: a standard nutrient package diet ( $2 \times 2 \mathrm{~N} \mathrm{SP}, 2 \times 3 \mathrm{~N} \mathrm{SP})$, or an iso-energetic nutrient boosted package $(2$ $x 3 \mathrm{~N} B P$ ) until market size. $3 \mathrm{~N}$ groups initially grew significantly faster than $2 \mathrm{~N}$, and by harvest, $3 \mathrm{~N}$ BP weighed significantly more $(3210 \pm 87 \mathrm{~g})$ than $2 \mathrm{~N}$ SP or $3 \mathrm{~N}$ SP $(3007 \pm 64 \mathrm{~g} ; 2965 \pm 88 \mathrm{~g})$, while there was no significant difference in weight between ploidy in SP diet. Higher visible vertebral $(9.6 \pm 0.4 \%)$ and jaw deformities $(10.6 \pm 1.2 \%)$ were observed in $3 \mathrm{~N}$ compared to $2 \mathrm{~N}(0.9 \pm 0.1 \% ; 1.3 \pm 0.5 \%)$.

However, x-ray radiography revealed that $3 \mathrm{~N}$ BP and $2 \mathrm{~N}$ SP had comparable levels of severely affected individuals to that at time of sea transfer, while $3 \mathrm{~N}$ SP showed a 3 fold increase in the severity of malformed individuals. The tail region (R3) in 3N SP fish had both the lowest vertebral strength and stiffness and the highest number of deformed vertebrae. Fillet quality attributes were comparable between diet and ploidy. These findings showed that triploid growth rate can be sustained until harvest throughout the seawater phase by using a nutrient boosted diet, and furthermore, the progression of spinal deformity beyond that at sea transfer can be stabilised by increasing dietary $\mathrm{P}$ during the marine phase.

Suggested Reviewers: Per Gunnar Fjelldal PhD

Institute of Marine Research, University of Bergen

pergf@IMR.no

research in triploid physiology and nutrition

Thomas Fraser PhD

Norwegian School of Veterinary Science

tom.fraser@nvh.no

research in triploid physiology

Tillman Benfey PhD

University of New Brunswick

benfey@unb.ca

fish physiology 
Stephane Fontagne PhD

INRA

fontagne@st-pee.inra.fr

Fish nutritionist

Opposed Reviewers: 
Dear Prof. Gatlin,

Please find a research article entitled "Nutrient supplementation enhances seawater growth and reduces severity of vertebral malformation in triploid Atlantic salmon (Salmo salar)" for consideration for publication in Aquaculture. The study generates new data on dietary requirements of triploid Atlantic salmon that provides a significant improvement in farmed triploid welfare, allowing exploitation of faster growth rates and highlights the need to develop "triploid specific" aquafeeds rather than the use of conventional diploid diets.

We look forward to receiving your feedback.

Yours sincerely,

Dr. John Taylor

Research Fellow, Institute of Aquaculture 
- Triploid Atlantic salmon growth rate can be sustained during marine rearing using nutrient boosted diets

- Progression of skeletal malformation development can be prevented during marine rearing of triploid Atlantic salmon by increasing dietary phosphorous

- The occurrence of skeletal malformation in triploid Atlantic salmon must be addressed during freshwater rearing in the first instance 
This study demonstrates that triploid Atlantic salmon have higher dietary requirements than their diploid siblings and that supplementing dietary phosphorous can prevent further progression of deformity during marine rearing. Tailored triploid specific aquafeeds must be formulated to support growth and prevent deformity in order to minimise welfare implications and allow exploitation of faster growth potential of triploid salmon within industry. 


\section{NUTRIENT SUPPLEMENTATION ENHANCES SEAWATER GROWTH AND REDUCES SEVERITY OF VERTEBRAL MALFORMATION IN TRIPLOID ATLANTIC SALMON (Salmo salar L.)}

Smedley, M. A. ${ }^{1}$, Clokie, B.G.J ${ }^{1}$, Migaud, H. ${ }^{1}$, Campbell, P. ${ }^{2}$, Walton, J. ${ }^{2}$, Hunter, D ${ }^{3}$, Corrigan, $\mathrm{D}^{3}$, Taylor, J.F. ${ }^{1 \dagger}$.

${ }^{1}$ Institute of Aquaculture, University of Stirling, Stirling, Scotland, UK

${ }^{2}$ Biomar, Grangemouth, Scotland, UK

${ }^{3}$ Marine Harvest Scotland, Fort William, Scotland, UK

$†$ Corresponding author, Dr J. Taylor

Tel +44 1786 477929; Fax: +44 1786472 133; E-mail address: jft2@stir.ac.uk

Running Title: Nutrient supplementation supports triploid salmon development

Keywords: Triploid; Salmon; Phosphorous; Nutrition; Deformity. 


\section{Abstract}

Diploid (2N) and triploid (3N) sibling post-smolts were divided between six sea pens

2 and fed: a standard nutrient package diet $(2 \times 2 \mathrm{~N} \mathrm{SP}, 2 \times 3 \mathrm{~N} \mathrm{SP})$, or an iso-energetic nutrient boosted package $(2 \times 3 \mathrm{~N} B P)$ until market size. $3 \mathrm{~N}$ groups initially grew significantly faster

4 than $2 \mathrm{~N}$, and by harvest, $3 \mathrm{~N}$ BP weighed significantly more $(3210 \pm 87 \mathrm{~g})$ than $2 \mathrm{~N}$ SP or $3 \mathrm{~N}$

5 SP $(3007 \pm 64 \mathrm{~g} ; 2965 \pm 88 \mathrm{~g})$, while there was no significant difference in weight between

6 ploidy in SP diet. Higher visible vertebral $(9.6 \pm 0.4 \%)$ and jaw deformities $(10.6 \pm 1.2 \%)$

7 were observed in $3 \mathrm{~N}$ compared to $2 \mathrm{~N}(0.9 \pm 0.1 \% ; 1.3 \pm 0.5 \%)$. However, $\mathrm{x}$-ray radiography

8 revealed that $3 \mathrm{~N} \mathrm{BP}$ and $2 \mathrm{~N} \mathrm{SP}$ had comparable levels of severely affected individuals to that

9 at time of sea transfer, while $3 \mathrm{~N}$ SP showed a 3 fold increase in the severity of malformed

10 individuals. The tail region (R3) in 3N SP fish had both the lowest vertebral strength and

11 stiffness and the highest number of deformed vertebrae. Fillet quality attributes were

12 comparable between diet and ploidy. These findings showed that triploid growth rate can be

13 sustained until harvest throughout the seawater phase by using a nutrient boosted diet, and

14 furthermore, the progression of spinal deformity beyond that at sea transfer can be stabilised

15 by increasing dietary $\mathrm{P}$ during the marine phase. 
Commercial adoption of triploid Atlantic salmon (Salmo salar) is being considered in

Europe due to their potential for faster growth compared to diploids (Taylor et al., 2012;

Fraser et al., 2013b) and to remove the risk of interbreeding between escapees and wild populations (McGinnty et al., 2003). However, although growth in freshwater is generally superior than diploids (Fjelldal \& Hansen, 2010; Taylor et al., 2012), it is the loss of growth at sea (Fraser et al., 2013b; Taylor et al., 2013) and increase in skeletal deformity (Fjelldal \& Hansen, 2010; Leclercq et al., 2011; Taylor et al., 2011) and cataract (Taylor et al., 2015) that have hindered full scale uptake as these traits reduce harvest weight (Hansen et al., 2010), increase production time and downgrading (Michie et al, 2001), and raise welfare concerns (Hansen et al., 2010). Aetiologies of skeletal malformations in diploid Atlantic salmon are well documented and include high egg incubation temperatures (Wargelius et al., 2005), genetic factors (Gjerde et al., 2005), vaccination (Berg et al., 2006), S0+ smolt regimes (Fjelldal et al., 2006) and nutritional deficiencies (Lall \& Lewis-McCrea, 2007) in particular dietary phosphorous (P) (Baeverfjord et al., 1998; Fjelldal et al., 2009; Fjelldal et al., 2012). It is now recognised that triploids should be treated as a 'new species' and environmental optima, disease resistance, behavioural and nutritional requirements must be defined in order that stock performance be at least comparable, if not better than diploids (Fraser et al., 2012a) triploid salmon culture in order to fully meet the nutritional requirements of the animals for somatic growth and metabolic function. However, to date, virtually all studies exploring production traits of triploids have used standard commercial diets formulated for diploids, and specific experiments on triploid nutritional requirements are limited (Burke et al., 2010; 
utilisation and behavioural feeding characteristics (Olivia-Teles \& Kaushik, 1990; Carter et al., 1994; Preston et al., 2014). However, recent research suggests triploid fish may have a higher nutritional requirement for growth than diploids in part related to altered metabolic function and differential gene regulatory pathways. In rainbow trout (Oncorhynchus mykiss) a series of studies have shown that triploids have increased fatty acid turnover due to increased $\beta$-oxidation in the liver (Manor et al., 2015); increased potential for muscle protein gain compared to diploids (Cleveland et al., 2012); lower expression of autophagy-related genes (atg $4 b$ and $l c 3 b$ ), indicative of lower rates of protein catabolism (Cleveland \& Weber, 2013); improved anabolic signalling in peripheral tissues by increased free IGF-I in the plasma, and altered expression of muscle regulatory factors, leading to improved myogenesis and muscle growth (Cleveland \& Weber, 2014). Given that the rate of protein accumulation in skeletal muscle largely determines growth rate (Bureau et al., 2006) and that a positive correlation exists between amino acid consumption and rate of protein synthesis (Houlihan et al., 1995), it is possible that triploids have higher protein and amino acid requirements for growth if feed intake cannot be increased to meet demand or dietary formulations are not sufficient to meet requirements. To date no commercial feed charts exist for recommended feeding rates of triploid Atlantic salmon. In addition specific dietary essential amino acid (EAA) and protein requirement studies have yet to be conducted in triploid Atlantic salmon. However, evidence exists to show a higher dietary histidine (His) requirement to prevent cataracts in triploids (17 vs. $12 \mathrm{~g} \mathrm{~kg}^{-1}$ ) (Taylor et al., 2015) while there is a known differential His requirement for growth or cataract prevention in diploid salmon (Remo et al., 2014). Thus other protein and essential amino acids requirement studies are essential as it is well established in diploid salmon that EAA deficiencies such as methionine can lead to growth depression and 
Nutritional supplementation is also known to mitigate skeletal malformation in diploid salmonids (Lall \& Lewis-McCrea, 2007) and may have potential for improvement of triploid skeletal health (Fraser et al., 2012a) particularly dietary phosphorous supplementation. In diploid post-smolts, less skeletal deformity, higher mineral retention and increased vertebral strength was observed in fish fed high dietary $\mathrm{P}\left(9.3 \mathrm{~g}\right.$ available $\left.\mathrm{P} \mathrm{kg}^{-1}\right)$ than those without supplementation (6.3g available $\mathrm{P} \mathrm{kg}^{-1}$ ) when fed for 17 weeks immediately following sea transfer (Fjelldal et al., 2009). By contrast a similar study using comparable dietary P levels but at later stage (>200g) post-sea transfer found no beneficial effect on malformation suggesting a stage specific requirement (Gil-Martens et al., 2012). More recently, Fjelldal et al. (2015) demonstrated that feeding $9.4 \mathrm{~g}$ total $\mathrm{P} \mathrm{kg}^{-1}$ to triploid Atlantic salmon from first feeding throughout freshwater rearing minimised skeletal malformations at the end of saltwater ongrowing and improved final weight when subsequently fed a standard seawater diet relative to those previously fed a lower P diet (7.1g total $\mathrm{P}^{-1}$ ). However, feeding high $\mathrm{P}$ diets during hatchery rearing raises environmental sustainability concerns due to the potential for eutrophication of freshwater bodies by increased $\mathrm{P}$ discharge. As yet triploid dietary $\mathrm{P}$ requirements for optimal skeletal development in saltwater are yet to be defined and may provide a means to stabilising skeletal malformation while minimising environmental impacts.

Thus the aim of the present study was to investigate whether a diet supplemented with increased dietary phosphorous and protein during seawater grow-out of triploid Atlantic salmon could reduce vertebral malformations whilst sustaining growth in comparison to triploids fed a standard commercial diploid diet. 


\section{Methods and Materials}

\subsection{Fish Stock and Husbandry}

On $26^{\text {th }}$ November 2010, fish eggs $(20,000 /$ ploidy) from the Aquagen strain were induced for triploidy at the Aquagen Broodstock Site, Hemne, Norway. Triploidy was induced using a hydrostatic pressure shock of 655 bar applied 37 minutes post fertilisation for 6.25 minutes at $8^{\circ} \mathrm{C}$. Eyed ova $\left(\sim 380^{\circ}\right.$ days $)$ were transferred to Marine Harvest Inchmore Hatchery, Glenmorriston, Scotland $\left(57^{\circ} \mathrm{N}, 5^{\circ} \mathrm{W}\right)$ on $13^{\text {th }}$ of January 2011 and on-grown under commercial protocols (Thermal regime: eye-hatch, $4.4 \pm 0.8^{\circ} \mathrm{C}$; hatch $-1^{\text {st }}$ feed, $5.9 \pm 1.6^{\circ} \mathrm{C}$ ). First feeding fry were reared under constant light (LL) and ambient water temperature (12.0 \pm $\left.2.2^{\circ} \mathrm{C}\right)$. On the $9^{\text {th }}$ of August 2011 , fry $(\sim 5 \mathrm{~g})$ were transferred to the Glenfinnan cage site and raised in two separate pens $10 \times 10 \times 5 \mathrm{~m}$ ( 1 / ploidy) under ambient photoperiod and water temperature $\left(9.9 \pm 3.1^{\circ} \mathrm{C}\right)$ and fed a standard diploid salmon feed (Skretting, UK) according to manufacturer's guidelines until sea transfer. Fish were vaccinated on the 16th November 2011 with Birnagen Forte. Completion of smoltification was verified in house by gill $\mathrm{Na}^{+}, \mathrm{K}^{+}$ ATPase activity (McCormick 1993) and skin silvering (Sigholt et al., 1995). Diploid control groups had significantly smaller nuclear lengths than pressure shock triploid groups (2 N 6.9$7.8 \mu \mathrm{m} ; 3 \mathrm{~N} 9.1-10.2 \mu \mathrm{m}$ ) confirming that all fish that were subjected to hydrostatic pressure shock were likely to be triploids. All experimental procedures and husbandry practices used in the present study were conducted in compliance with the Animals Scientific Procedures Act 1986 (Home Office Code of Practice) in accordance with EU regulation (EC Directive 86/609/EEC) and approved by the Animal Ethics and Welfare Committee of the University of Stirling. 


\subsection{Experimental Design}

On $5^{\text {th }}$ April 2012 , triploid smolts (mean weight $79.0 \pm 17.4 \mathrm{~g}$ ) were transferred to seawater (SW) at Marine Harvest Ardnish Farm Trial Unit, Lochailort, Scotland $\left(57^{\circ} \mathrm{N}, 6^{\circ} \mathrm{W}\right)$ and divided into four $10 \times 10 \times 15 \mathrm{~m}$ pens, $(\mathrm{n}=6625 /$ pen). Diploids (mean weight $88.0 \mathrm{~g} \pm$ $20.8 \mathrm{~g}$ ) smolted later and were transferred on $28^{\text {th }}$ of April to two pens ( $\mathrm{n}=6625 /$ pen). All fish up until the $20^{\text {th }}$ of June were fed a standard commercial feed (Biomar, CPK) after which duplicate pens of diploid and triploid smolts were fed a standard nutrient package (SP), while a further two pens of triploids were fed a boosted nutrient package (BP). Feed formulations for the experimental period are provided in Table 1 . Fish were handfed three times daily in accordance with manufacturer feeding table recommendations and feed recorded daily. Due to the scale of the study no feed collection devices were used and satiation was observed visually. Mortality, environmental data including water temperature, salinity, dissolved oxygen and clarity was recorded on a daily basis (Fig. 1).

\subsection{Sampling Protocol}

In June, July, September and November 2012 a total of 100 fish / pen were anaesthetised (50ppm MS222, Pharmaq, UK) and individual body weight (BW $\pm 10 \mathrm{~g})$ and fork length $(\mathrm{FL} \pm 0.5 \mathrm{~cm})$ recorded. Each fish was assessed for cataracts using a handheld ophthalmoscope according to Wall \& Richards (1992) and externally assessed for vertebral and jaw deformities in accordance with Taylor et al. (2014). Weight data was used to calculate thermal growth coefficient (TGC) and feed conversion rate (FCR) for each sampling period until harvest where TGC was calculated as: $\left(W_{\mathrm{f}}^{1 / 3}-W_{\mathrm{i}}^{1 / 3}\right) \times\left(\sum D^{\mathrm{o}}\right)^{-1}$, where $W_{\mathrm{f}}$ is the final body weight, $W_{\mathrm{i}}$ is the initial body weight and $D^{\mathrm{o}}$ is the cumulative sum of water temperature in degrees per day. FCR was calculated as: $F /\left(B_{\mathrm{f}}-B_{\mathrm{i}}+B_{\mathrm{m}}\right)^{-1}$ where $F$ is the food 
fed $(\mathrm{kg}) B_{\mathrm{f}}$ is the final biomass $(\mathrm{kg}), B_{\mathrm{i}}$ is the initial biomass $(\mathrm{kg})$ and $B_{\mathrm{m}}$ is the mortality biomass for the period $(\mathrm{kg})$.

On the $7^{\text {th }}$ February 2013 a final sampling was carried out prior to harvest. From the 100 fish anaesthetised / pen, terminal samples were collected (10 and 20/pen for $2 \mathrm{~N}$ and $3 \mathrm{~N}$ respectively) using a percussive blow to the head and severing of the gill aorta in accordance with schedule 1 UK Home Office procedure. Triploid fish were subjectively selected according to normal/no visible deformity $(\mathrm{n}=10 /$ pen) or the appearance of externally observable lower jaw deformity $(n=5 /$ pen) or vertebral deformity $(n=5 /$ pen). The heart was dissected out from each fish and preserved in $10 \%$ neutral buffered formalin. Fish were number tagged using a cable tie, placed in polystyrene boxes, packed flat with ice and left for 72 hours to achieve rigor prior to fillet quality analysis.

From Feb $25^{\text {th }}$ one pen per day was harvested according to commercial protocol. 500 fish per pen were individually assessed for externally visible deformities on each harvest day to determine overall deformity prevalence within each cage population. All harvested fish were classified as superior, ordinary or rebate according to Marine Harvest Quality standards.

\subsection{Parameters analysed}

\subsubsection{Fillet Quality}

Of terminal samples collected at harvest per pen $(2 \mathrm{~N}=10 /$ pen; $3 \mathrm{~N}=20 /$ pen $)$, the left hand side fillet was carefully removed for flesh quality analysis carried out with the assistance of Biomar (Grangemouth, UK). Fillets were assessed for pigmentation inside a light box using Roche SalmoFan Lineal Card (Hoffman-La Roche, Basel, Switzerland) scoring by two independent observers (Roche SOP). Fillets were then assessed for gaping and texture (Biomar SOP). A Norwegian quality cut (NQC) was removed from each fillet and 
frozen for later fatty acid composition analysis using near-infrared NIR analysis and additional pigment analysis (Marine Harvest SOP).

\subsubsection{Texture Analysis}

Texture analysis was carried out according to Johnston et al. (2004). Briefly, two cuboid sections of flesh were removed from the side fillet below the dorsal fin measuring $20 \mathrm{~mm} \times 40 \mathrm{~mm} \times 40 \mathrm{~mm}$ and chilled to $4^{\circ} \mathrm{C}$ before analysis was carried out using a texture analyser (TA-HDi Texture Analyser, Stable Micro Systems, Haslemere, UK) with a steadily advancing Warner-Bratzler blade set to travel at $1 \mathrm{~mm}$ second ${ }^{-1}$. The cutting load was continuously recorded and used to calculate the maximum force $(\mathrm{N})$ required and the total work done (WD).

\subsubsection{Heart Morphology}

Sample hearts were pinned and photographed with the cranio-ventral surface facing uppermost before being turned and photographed from a side view according to the method of Poppe et al. (2003). Image analysis was carried out on each using Fiji (version 1.47b, NIH, USA). Heart width and height was measured along with the angle of the bulbous arteriosis. The heart was squeezed to remove excess fixative and weighed to calculate the cardiosomatic index $(\mathrm{CSI})$ such that CSI $=(100 \mathrm{x}$ Heart Weight $(\mathrm{HW})) /$ Body Weight $(\mathrm{BW}))$.

\subsubsection{Vertebra Radiological Assessment}

After careful removal of the side fillet, two radiographs (anterior and posterior) were taken of each fish using a portable x-ray unit (Celtic SMR PX40 HF) with an extremity plate measuring $24 \times 30 \mathrm{~cm}$, and each plate exposed for $32 \mathrm{mAs}$ at $40 \mathrm{kV}$. Images were then digitized (AGFA CR-35X) and radiographs examined using Adobe Photoshop CS 6 (version 
13.0.1, Adobe system Incorporated, California, USA). The spine was divided into four regions (R1, 2, 3, and 4) as per Kacem et al. (1998), and deformities classified based on Witten et al. (2009), with the total number of vertebra recorded for each fish.

\subsubsection{Vertebra Mechanical Properties}

Vertebra number 6, 7, and 8 from the anterior region (R1), v28, 29 and 30 from the middle region (R2/3) and $v 52,53$ and 54 from the caudal region (R4) were carefully dissected out post radiography. Each vertebra was crushed individually $(\mathrm{n}=3$ vertebra / region / pen) using a texture analyser fitted with a $10 \mathrm{~cm}$ compression plate (TA-HDi Texture Analyser, Stable Micro Systems, Haslemere, UK) to a distance of $4 \mathrm{~mm}$ at a speed of $0.1 \mathrm{~mm} / \mathrm{s}$. Yield Load $(\mathrm{N})$, Stiffness $(\mathrm{N} / \mathrm{mm})$ and resilience $(\mathrm{N} \times \mathrm{mm})$ were calculated for each vertebra according to modified protocols of Fjelldal et al. (2004). After mechanical crushing, the three vertebrae from each region were pooled and mechanically stripped of any remaining flesh, defatted in baths of iso-hexane for 24 hours, oven dried at $105^{\circ} \mathrm{C}$ for 24 hours and incinerated at $600^{\circ} \mathrm{C}$ for 16 hours. Weights $\left(1 \times 10^{-3} \mathrm{mg}\right)$ of dried and ashed vertebrae were used to calculate the Bone Mineral content (BM\%) of each region according to Fjelldal et al. $(2006)$ as Mineral content $=($ ashed weight $/$ dry weight $) \times 100$. Samples were then digested in nitric acid using a Mars Microwave digestion system (10 min. heating phase to $160^{\circ} \mathrm{C}, 20 \mathrm{~min}$. at $160^{\circ} \mathrm{C}, 30 \mathrm{~min}$. cooling phase) and analysed for inorganic elements by Inductively Coupled Plasma Mass Spectrometry (ICP-MS) using a Thermo X Series II ICPMS (collision cell model). Percentage concentrations were calculated for Phosphorous, calcium, magnesium, zinc and vanadium. 


\subsection{Statistics}

Results are reported as mean \pm standard error of the mean (SEM). Statistical analysis was carried out using Minitab (Version 16.2.3, Minitab Inc, Pennsylvania, USA). Differences between weight, $\mathrm{K}$, and flesh quality parameters were assessed using a general linear model (GLM) and one-way ANOVA with replicates nested within treatment. Statistically significant differences were consider as $\mathrm{p}<0.05$. Post hoc tests were carried out using Tukeys multiple comparisons. Two-way ANOVA manipulated through GLM was used to analyse heart morphology, bone mineral and bone strength attributes. All proportions were transformed using arcsine and all data were checked for normality using a Kolomogorov-Smirnov test and homogeneity of variance using Levene's test and observations of residual plots. X-rays of deformed vertebrae were ranked according to severity and analysed for differences using a PERMANOVA (Version 1.6, University of Auckland, New Zealand).

\section{Results}

\subsection{Growth and Mortality}

From June to September, both triploid groups maintained a significantly higher weight than diploids (Fig. 2a). Furthermore, from July to September, 3N BP attained a significantly higher weight than 3N SP. Greater weight was reflected in a higher TGC and more efficient FCR (Fig. 2a,b) of both triploid diets than diploids during period 1. However, both $3 \mathrm{~N}$ dietary groups TGC significantly decreased and FCR was less efficient during period 2 and 3, as such there was no significant difference in weight between any treatment by mid-November. Diploids also showed a marked reduction in TGC and FCR efficiency between September and November. This period of reduced growth and feeding efficiency (July-November) coincided with a combined outbreak of amoebic gill disease (Neoparamoeba perurans) and heart and skeletal muscle inflammation (HSMI). During this period there was also a 
concomitant decrease in $\mathrm{O}_{2}$ saturation and higher water temperature (Fig. 1). Cumulative mortality levels were comparable (2N SP: $3.83 \pm 0.68 ; 3 \mathrm{~N} \mathrm{SP}: 3.64 \pm 0.34 ; 3 \mathrm{~N}$ BP: $3.75 \pm$ 1.21) during this period, and overall mortality for the duration of the trial did not differ significantly between any treatment and was $6.7 \pm 1.0,7.4 \pm 0.1$ and $6.8 \pm 1.8 \%$ for $2 \mathrm{~N} \mathrm{SP}$, 3N SP and 3N BP respectively. From November onwards, water temperature cooled and fish showed signs of recovery whereby $3 \mathrm{~N}$ BP achieved a significantly greater final harvest weight than $3 \mathrm{~N}$ SP or $2 \mathrm{~N}$ SP dietary groups. Irrespective of dietary treatment, triploids maintained a significantly lower K than diploids from September until harvest (Fig. 2c).

\subsection{Deformity}

\subsubsection{Cataract and Externally Visible Deformity}

Cataract prevalence at harvest was very low in this study (incidence of $2.0 \pm 1.0 \%$ ) with a mean score of $2.9 \pm 1.6$ for affected individuals and did not differ between ploidy (data not shown).

At harvest both triploid dietary groups exhibited similar levels of external deformity (19-21\%) in comparison to diploids $(\sim 2.2 \%)$ with jaw and vertebral pathologies accounting for approximately equal proportions of deformity (9.3-11.4\%) within triploid treatments (Table 2a).

\subsubsection{Radiological Deformity}

X-ray assessment showed that triploids had on average one less vertebra than diploids (Table 2 b). At smolt, $37 \%$ of diploids and $76.4 \%$ of triploids were classified as radiologically deformed, having at least 1 or more deformed vertebra (dV). Triploids also had a significantly higher number of $\mathrm{dV}$ per deformed fish than diploids at smolt, and only triploids showed individuals with 6-9dV or $\geq 10 \mathrm{dV}$ (Table $2 \mathrm{~b}$ ). 
At harvest, diploids showed a slight increase $(+3 \%)$ in radiologically deformed individuals $(40 \%)$ compared to that at smolt, while triploids showed a greater increase $(+8.6 \%)$, with $85 \%$ of fish classified as radiologically deformed (Table $2 \mathrm{~b}$ ). $3 \mathrm{~N}$ SP had a significantly higher average no. $\mathrm{dV}$ per deformed fish than $3 \mathrm{~N} \mathrm{BP}$, with $2 \mathrm{~N}$ SP having significantly lower average no. dV than either triploid dietary group. Finally, comparing fish with $\geq 10 \mathrm{dV}$ (i.e. likely to compromise welfare, Hansen et al., 2010) at harvest and smolt showed a small increase in $2 \mathrm{~N} \mathrm{SP}(+5 \%)$ and $3 \mathrm{~N}$ BP $(+1.1 \%)$, but a notable increase $(+31.1 \%)$ in $3 \mathrm{~N} \mathrm{SP}$ (Table $2 \mathrm{~b})$. Furthermore, a greater proportion of triploids were classified as having mild deformities (range 1-5dV) in the BP than SP diet ( 45\% vs. 10\%).

Deformed vertebrae were observed in all four spinal regions in triploids, but not in the cranial trunk (R1) in diploids, with the predominate locality of all deformed vertebrae in the tail region (R3), principally v39-v43, irrespective of ploidy (Fig 3a). Triploid dietary groups did not differ significantly in total deformed vertebrae in R1 (Fig. 3b), while 3N SP had significantly higher deformed vertebrae in R2 than $2 \mathrm{~N} \mathrm{SP}$, with $3 \mathrm{~N}$ BP intermediate to both, and not differing significantly from either ploidy on the SP diet. A similar pattern was reflected in the tail region (R3), with $3 \mathrm{~N}$ BP showing a reduced prevalence to $3 \mathrm{~N}$ SP, and statistically comparable to 2N SP (Fig. 3b). Finally, no significant differences between treatments were observed in the tail fin (R4). Of deformity types observed compression type Ploidy and diet had a significant effect on vertebral L:H ratio (Fig. 3c). In R1 and R2 triploids had a significantly higher $\mathrm{L}: \mathrm{H}$ ratio than diploids irrespective of diet. In $\mathrm{R} 3,3 \mathrm{~N}$ SP had a significantly higher L:H ratio than $3 \mathrm{~N}$ BP (mean: $0.94 \pm 0.00$ vs. $0.92 \pm 0.01$ ), predominantly evident in $\mathrm{v} 45-\mathrm{v} 49$, which were significantly higher than $2 \mathrm{~N}$ SP (mean $0.89 \pm$ 
0.01). Finally, no significant difference in L:H ratio was observed between ploidy or diet in R4.

\subsection{Vertebral Composition and Strength}

Total mineral content did not differ between spinal region in $2 \mathrm{~N}$ SP or $3 \mathrm{~N}$ SP groups

(Fig. 4a). There was no significant difference between R1 and R2/R3 within 3N BP, however,

R4 had a significantly lower mineral content than R2. Comparing all three treatments, R2/R3

had comparable total mineral content, while $2 \mathrm{~N}$ SP had a significantly higher mineral content than 3N BP in both R1 and R4.

Vertebral mineral analysis revealed no significant differences between regions for

specific minerals, as such all vertebra data were pooled per treatment (Table 3). Calcium content was significantly higher in $2 \mathrm{~N}$ SP than $3 \mathrm{~N}$ BP, but not $3 \mathrm{~N}$ SP, while phosphorous content was significantly higher in $2 \mathrm{~N}$ SP than either of the triploid groups. By contrast, $\mathrm{Ca}: \mathrm{P}$ ratio did not differ between any treatment. Magnesium content was significantly higher in $2 \mathrm{~N}$ SP than $3 \mathrm{~N}$ BP, but not $3 \mathrm{~N}$ SP, although no difference between triploids was observed. Vanadium content was significant higher in $3 \mathrm{~N}$ BP than either ploidy in the SP diet. Both $2 \mathrm{~N}$ SP and 3N SP had significantly higher vertebral zinc content than 3N BP.

Vertebral stiffness did not differ significantly within region between treatments (Fig.

4b). Lowest stiffness was generally observed in R1 and highest in R2/R3. Mechanical testing showed significant differences in the yield load $(\mathrm{N})$ between the three regions with R1 demonstrating the lowest yield load, R4 then R2/R3 (Fig. 4c). No significant difference between the three dietary groups was found within $\mathrm{R} 1$ and $\mathrm{R} 2 / 3$. In $\mathrm{R} 4,3 \mathrm{~N}$ SP showed a significantly lower value than $2 \mathrm{~N}$ SP. No significant differences were observed between $3 \mathrm{~N}$ $\mathrm{BP}$ and 2N SP. R2/R3 showed a significantly higher resilience $(\mathrm{N} \times \mathrm{mm})$ than any other region with the lowest resilience observed in R1 (Fig. 4d). No significant differences were 
found between treatments within R1. In R2/R3 and R4, 2N SP resilience was significantly higher than 3N SP but there was no statistical difference between 2N SP and 3N BP groups.

\subsection{Heart morphometrics}

No significant differences between ploidy or diet were found for CSI $(0.17-0.18)$ and $\mathrm{H}: \mathrm{W}$ ratio $(0.09-1.12)$. A significant difference was however found between the angle of the bulbous arteriosis between the $2 \mathrm{~N} \mathrm{SP}(35.9 \pm 1.6)$ and $3 \mathrm{~N} \mathrm{SP}(30.9 \pm 1.4)$ but not the BP diet $(34.7 \pm 1.1)$ (data not shown). or $3 \mathrm{~N}$ BP (Table 5a). Consequently, the proportion of fish classed as ordinary was higher for the triploid dietary groups. Rebate for 3N SP was significantly higher than 3N BP. 2N SP had

\subsection{Harvest Weight \& Fillet Quality}

Size classification at harvest varied between the dietary groups and there was an overall trend towards larger fish in triploids than diploids with triploid BP showing a greater proportion of fish in the 3-4 and 4-5kg grades (Fig. 5a). By contrast, $51.6 \pm 3.78 \%$ of fish harvested in $2 \mathrm{~N} \mathrm{SP}$ weighed in the smaller weight class of $2-3 \mathrm{~kg}$ compared to $32.9 \% \pm 1.3 \%$ in $3 \mathrm{~N}$ BP and $38.2 \pm 2.8 \% 3 \mathrm{~N} \mathrm{SP}$.

In both diploids and triploids, fish with jaw malformation showed a lower harvest weight than those without (Table 4). In diploids, vertebral deformity did not affect harvest weight, by contrast, harvest weight was significantly higher in triploids with visible vertebral deformity than those without. Condition factor was also significantly higher in the fish with vertebral deformities in all ploidy groups, while those with jaw malformation showed a tendency towards a lower condition factor (Table 4).

Final harvest saw a greater proportion of fish classed as superior in $2 \mathrm{~N}$ SP than $3 \mathrm{~N}$ SP the lowest level of rebate at harvest. The major cause of downgrading were mainly 
attributable to thin, misshapen, runts and mechanical damage, with triploids showing a higher relative proportion than diploids (Fig. 5b).

Total percentage fillet fat, DHA content, and ratio of n-3:n-6 fatty acids did not differ significantly between ploidy or diet (Table 5b). EPA was significantly higher in $3 \mathrm{~N}$ SP than 3N BP $(P=0.01)$. Fillet pigment content was significantly lower in both triploid groups relative to diploids, but did not differ between triploid dietary groups (Table 5c). Although Roche scores did not show significant difference between treatments and ploidy, scores did correlate with reduced total pigment. Fillet texture, gaping, or mechanical strength showed no significant difference between diet and ploidy (Table 5d).

\section{Discussion}

This study successfully demonstrated that triploid Atlantic salmon growth rate can be superior to diploids, and more importantly, sustained until harvest when fed a nutrient enriched diet rather than a conventional diploid diet. Furthermore, by supplementing dietary $\mathrm{P}$ in the marine phase, progression of skeletal malformation was successfully stabilised and is a major step forward towards improving triploid welfare.

Triploids fed the boosted nutrient diet showed significantly greater growth during the trial, achieving a $+7 \%$ greater mean body weight at harvest than diploids or triploids reared on a standard commercial diploid diet. This is one of only two studies to show triploid growth can actually be sustained at a higher rate over the entire marine phase (Oppedal et al., 2003). By comparison, triploids fed the standard diet also showed a significantly higher growth rate than diploids but only in the first 5 months before weight advantage was lost and this is consistent with previous studies to date (O'Flynn et al., 1997; Friars et al., 2001; Cotter et al., 2002; Leclercq et al., 2011; Fraser et al., 2013b; Taylor et al., 2013; Tibbets et al., 2013). 
356 Collectively, these differences in growth potential of triploids between the two diets in the 357 current study clearly demonstrate that triploids do indeed appear to have a higher nutritional requirement to support growth.

Given that the rate of protein accumulation in skeletal muscle largely determines growth rate (Bureau et al., 2006) and that a positive correlation exists between amino acid consumption and rate of protein synthesis (Houlihan et al., 1995) it is likely that triploids fed the nutrient boosted package, benefited from increased inclusion of dietary protein, $+7 \%$, which then facilitated sustained muscle growth. This would agree with observations in triploid rainbow trout which have been shown to have higher protein synthesis rates (Cleveland et al., 2012), reduced protein catabolism (Cleveland \& Weber, 2013) and improved myogenesis (Cleveland \& Weber, 2014) which are all suggestive of different metabolic rates between ploidy. In this respect, increasing dietary protein may also be having an energy sparing effect (Tibbets et al., 2013) as non-protein energy source (oil) were comparable between the standard and nutrient boosted diets, and given that triploids have different fatty acid turnover rates (Manor et al., 2015) this sparing effect may be conserving amino acids for protein biosynthesis. Finally, during the high growth periods of this study, triploid FCR was also more efficient than diploids. Thus, in theory, per kilogram of feed consumed triploids on the standard diet would be consuming less nutrients per kilogram of muscle growth than would be theoretically available through the nutrient boosted package. This potential nutrient shortfall may also reflect why triploids have been reported to have higher feed intakes to compensate for resource deficiency (Cleveland \& Weber, 2013) and are more prone to nutritional deformities. Furthermore, feeding rates are traditionally assessed in diploids through confirmation of satiation by surface observations. However, observations in this study suggested a deeper feeding behaviour as previously reported in brown trout, Salmo trutta, (Preston et al., 2014). If confirmed, this could mean satiation in 
older studies may not have been met in triploids. Successful production of triploids will thus rely on developing triploid specific feeding tables in addition to specific aquafeeds in order to provide optimum nutrition.

From late July to November, triploid growth rate (TGC) in both dietary groups dropped significantly compared to diploids. Peak water temperatures were achieved during this period with a concomitant reduction in oxygen saturation. In a previous study at the same site, Taylor et al. (2013) reported a similar drop in growth performance during the same period with comparable oxygen and temperature profiles. These observations are consistent with recent findings that showed triploid Atlantic salmon have reduced heart rate (Atkins \& Benfey, 2008), and lower aerobic metabolic scope at high temperature $\left(19^{\circ} \mathrm{C}\right)$ and moderate hypoxia (70\% $\mathrm{O}_{2}$ saturation) (Hansen et al., 2015). Thus the inability of triploid salmon to withstand extended periods of high temperature and moderate hypoxia could set limits to the geographical distribution of triploid salmon farming (Hansen et al., 2015). In the case of our study the reduced growth performance is highly likely a result of a metabolic compromise under the environmental conditions, further exacerbated by a combined outbreak of AGD and HSMI during this period. However, of significant importance is that during this "challenge" period, mortality rates did not differ between ploidy. Following a return to normal environmental conditions, both triploid groups recovered to pre-challenge growth rates, albeit recovery time was longer than diploids. Environmental and disease challenge pressures may place further strain on the cardiac system. In this respect it was evident that triploids under the standard diet had a more acute angle of the bulbus arterious at slaughter consistent with other studies in Atlantic salmon (Leclercq et al., 2011; Fraser et al., 2013b), suggestive that triploids could experience more cardiac workload to diploids. Although triploid heart morphology has been shown to be influenced by egg incubation temperature (Fraser et al., 2013a) and vaccination (Fraser et al., 2014b), it was also evident in our study that diet equally 
affected angle of the bulbus arterious, in that the nutrient boosted diet had a significantly

407 higher angle than those on the standard diet, and comparable to that in diploids. However,

408

409

410

411

412

413

414

415

416

417

418

419

420

421

422

423

424

425

426

427

428

429

430 what effect the angle of the bulbus arteriosus has on salmon heart function is currently unknown, and future studies on cardiac performance in triploids are suggested.

Finally, both triploid groups had lower condition factors than diploids from early autumn, suggestive of increased skeletal growth relative to muscle gain, and is again consistent with previous studies. Fjelldal et al. (2015) suggested that this diverging pattern between skeletal and somatic growth in triploids may have an effect on dietary P demand, as an animal with a rapidly growing skeleton will need a higher mineral input to support normal bone mineralization. However, examination of externally visible deformity at harvest did not reveal a difference in occurrence between triploids on the nutrient boosted or standard dietary packages. Nonetheless, and of fundamental importance was that x-ray radiography revealed that triploids fed the supplemented diet (+30\% dietary P) had three fold less fish (15 vs 45\%) with severe spinal deformities (i.e. $\geq 10 \mathrm{dV}$, that would be expected to affect welfare, according to Hansen et al., 2010) than their triploid siblings fed a standard commercial diet. Furthermore, the average number of deformed vertebrae per deformed fish remained more or less the same at harvest as the point of sea transfer (smolt) in the supplemented group (5.8 to 6.0), but had doubled in the standard dietary triploid group (from 5.8 to 11.5). Thus the progression of deformity during seawater in triploids was largely arrested by dietary supplementation suggesting that deformity in triploids may indeed be tackled by diet during the early seawater phase. Previously, mineral supplementation for 17 weeks following sea transfer has been shown to reduce spinal malformation in diploid post-smolts (Fjelldal et al., 2009). However, given the high prevalence of pre-existing malformation observed at smolt, a greater emphasis must be placed on egg incubation regimes and first feeding diets of triploids to minimise the occurrence of deformity in the first instance. 

and body weight was highest in those with compressive spinal deformities in accordance with Hansen et al. (2010), which may be indicative of pathology associated with fast growth rates under nutrient deficient conditions, while fish exhibiting jaw deformities were generally of lower weight $(-20 \%)$ than non-deformed fish, which may reflect impaired feeding or respiratory ability (Roberts et al., 2001; Venegas et al., 2003; Lijald \& Powell, 2009; Taylor et al., 2013). However, unlike spinal deformity, no positive effect of diet on reducing jaw malformation was evident in our study, although dietary vitamin $\mathrm{C}$ and $\mathrm{P}$ supplementation during seawater rearing have previously been suggested as preventive nutritional factors (Roberts et al., 2001). Jaw malformation may also be caused by mechanical stress and weakening of the lower jaw bones through excessive buccal-opercular pumping associated with high temperatures and reduced oxygen availability. It has recently been shown that incubating triploid eggs at lower temperature $\left(6^{\circ} \mathrm{C}\right)$ to the point of eyeing significantly reduced occurrence of jaw malformation (Fraser et al., 2014a), and that supplementing dietary P from first feeding in combination with low temperature incubation (Fjelldal et al., 2015) further reduces the occurrence of jaw deformity. This further supports the concept that these skeletal weaknesses may by inbuilt from early life stages during freshwater and should be tackled during the hatchery phase.

Fish bone strength is highly impacted by mechanical stress, and mechanical stimuli induce extra strength and vertebral support in the form of mineralisation (Lall \& LewisMcCrea, 2007; Ytteborg et al., 2013). In particular, the tail region (R3) undergoes the greatest mechanical strain due to lateral muscular activity and is the region most associated with spinal pathology in seawater (Fjeldall, et al., 2009; Totland et al., 2011). In our study this region not only displayed the highest occurrence of vertebral deformity, but also the greatest dietary effect on vertebral strength and morphology (L:H ratio). In general, diploids had the 
highest bone strength properties in each respective region, while triploids fed the standard

457 diet generally the weakest properties, and those on the boosted diet were intermediary to both, although differences were generally non-statistically significant. Decreased bone mineralisation and increased vertebral deformities in fast growing fish are considered features of a sub-optimal diet (Fjelldal \& Hansen, 2010) that manifest as reduced vertebral strength (Ytteborg et al., 2010) which were clearly evident in triploids fed the standard nutrient package diet. Furthermore, triploids also had higher L:H ratios than diploids in R1-R3 indicative of more elongated vertebral bodies within these regions as observed in triploid yearling smolts (Fraser et al., 2014a). In addition, L:H ratio was also affected by diet, being significantly higher in triploids fed the standard diet compared to those fed the supplemented diet in R3. Such changes in vertebral morphology could be attributed to the need for elongation of individual vertebral bodies to compensate for compressive pathologies (the most common pathology observed in this study) elsewhere within the spinal column, thus providing increased strength within the spine while under mechanical strain, particularly under conditions of mineral deficiency.

Hydroxyapatite $\left(\mathrm{Ca}_{5}\left(\mathrm{PO}_{4}\right)_{3}(\mathrm{OH})\right)$ is the key mineral structure in bone and its formation is limited through dietary $\mathrm{P}$ and $\mathrm{Ca}$ absorption directly from the aquatic environment (Lall \& Lewis-McCrea, 2007). NRC (2011) recommendations for dietary P for diploid Atlantic salmon are estimated at $8 \mathrm{~g} \mathrm{Kg}^{-1}$ available P. In seawater, Gil-Martens et al. (2012) failed to observe a reduction in vertebral deformity in diploid post-smolts using $6 \mathrm{~g}$ or $9 \mathrm{~g} \mathrm{~kg}^{-1}$ available P, whereas Fjelldal et al. (2012) found a reduction in vertebral 477 malformation in diploid smolts when previously fed $11.7 \mathrm{~g} \mathrm{~kg}^{-1}$ available $\mathrm{P}$ as opposed to $6.3 \mathrm{~g}$ 478 and $8.9 \mathrm{~g} \mathrm{~kg}^{-1}$. In a more recent study on triploid smolts, vertebral malformation was 479 prevented when previously fed $12 \mathrm{~g} \mathrm{~kg}^{-1}$ available P rather than $4 \mathrm{~g}$ or $6 \mathrm{~g} \mathrm{~kg}^{-1}$ (Fjelldal, et al., 2015). These observations are in agreement with Helland et al. (2005) who previously 
481 suggested that commercial levels $\left(<10 \mathrm{~g} \mathrm{Kg}^{-1}\right.$ total $\left.\mathrm{P}\right)$ may be too low for fast growing 482 salmon to maintain skeletal integrity. In the current study we observed clear beneficial effects on improved spinal health in triploid post-smolts by increasing total dietary P by $+20 \%(9.9$ vs. $\left.12 \mathrm{~g} \mathrm{P} \mathrm{kg}^{-1}\right)$.

Phosphorus is not only important for bone growth but also plays an essential role in many anabolic, catabolic and metabolic processes such as energy and DNA synthesis (Burke et al., 2010). Maintenance processes taking precedence over bone mineralisation offer a possible explanation of the high level of deformities in the triploid standard diet at the end of the trial. Although severity of deformity was improved in the nutrient boosted package, interestingly vertebral mineral content, $\mathrm{P}$ and $\mathrm{Ca}$ levels were in general lower than diploid and triploids fed the standard diet, thus suggesting that improvement of vertebral integrity through $\mathrm{P}$ supplementation is not simply through accumulation. Minerals such as $\mathrm{P}$ may be used preferentially to facilitate higher growth rates in the supplemented diet without compromising bone strength or stiffness. Higher levels of vanadium, a known biometal suppressor of ECM mineralisation (Tiago et al., 2008) were also observed in triploids fed the supplemented diet compared to the standard package diet, and may reflect suppressed hydroxyapatite formation in the presence of sufficient mineral resources for skeletal development, but as yet remains unclear. Certainly in the case of triploids fed the standard diet, deformed fish had significantly higher weights at harvest suggestive of spinal deformity being a function of fast growth under nutrient deficient conditions in the standard diet. Collectively these results indicate that the nutrient boosted package appears to facilitate better spinal mineralisation during development which would otherwise be compromised at the expense of accelerated growth under a standard diet. comparable to the diploid control and concur with other studies in triploid Atlantic salmon 
506 (Taylor et al., 2013). However, in this study we did observe a significant reduction in total 507 pigment in triploids relative to diploids. Differences in pigment and other flesh quality 508 attributes at harvest may also be highly influenced by season. Improved pigment retention 509 through reproductive arrestment has often been cited as a potential benefit for producers of 510 triploid salmon, although this has so far only been shown in rainbow trout (Choubert \& 511 Blanc, 1989; Choubert et al., 1997). However, fish in our study were harvested in February and would not be expected to entering into an active gonadal development at this stage, therefore we cannot relate these pigment differences to differing maturation rates between 514 ploidy. A positive relationship between visual colour score and muscle fibre density 515 independent of chemical pigment content has been reported in Atlantic salmon (Johnston et al., 2000), however, Bjørnevik et al. (2004) concluded that differences in muscle fibre structure between ploidy are not a major factor influencing flesh redness. It was however noted that texture may affect fillet redness, and similarly in our study we also found a decrease in pigment content with increased texture score, albeit non-significant. Reduced pigment deposition may also stem from the decreased surface area to volume ratio and/or binding affinity of triploid cells and requires further study to elucidate differences between ploidy.

In conclusion, this trial demonstrated that increased dietary supplementation of protein and phosphorous can achieve a higher growth rate in triploids compared to diploids or triploids fed a standard diploid seawater diet. Furthermore, of significant importance was that 526 the development of vertebral malformation beyond that present at time of seawater transfer 527 (i.e. smolt) could be stabilised and prevented from progressing further by increasing dietary $\mathrm{P}$ supplementation. However, the incidence of malformation observed at time of sea transfer still remains above ethically acceptable levels and supports reports in other studies whereby the initial formation of deformities should be addressed in freshwater through triploid specific 
531 diets and egg incubation temperatures. Finally, this study also provided anecdotal evidence

532 to suggest that triploid fish are not necessarily more susceptible to disease challenge, but they

533 are more sensitive to sub-optimal environmental conditions, particularly elevated temperature

534 and reduced oxygen saturation. Collectively, this study makes significant contributions

535 towards improving triploid welfare standards and achieving viable commercial

536 implementation.

537

538 Acknowledgements

539 This project was financially supported by combined contributions through EC project 540 SALMOTRIP (FP7, 222115), BioMar and Marine Harvest (Scotland) Ltd industrial award to 541 Dr Taylor and Prof. Migaud, and BBSRC Case PhD award (BB/J500835/1) to Marie 542 Smedley in association with Marine Harvest Scotland. The authors would like to give thanks 543 to Dr Ralph Bickerdie and Dr Daniel Leeming (BioMar), Graeme McWhinnie, James Dick 544 and Dr Matthew Sprague (University of Stirling) and laboratory staff at Marine Harvest 545 Scotland, Blar Mhor, Fort William for technical assistance in sample processing, and Prof. 546 James Bron (University of Stirling) for his statistical support. We would also like to thank the 547 staff at Ardnish Farm Trial Unit, Marine Harvest (Scotland) for their care of the fish 548 throughout this trial.

$550 \quad$ Figure Legends

551 Figure 1. Water temperature $\left({ }^{\circ} \mathrm{C}\right.$; black line) and oxygen saturation (\%; grey line line) for the 552 cage site during the trial period. Oxygen saturation has been corrected for salinity and 553 temperature.

554 
555

556

557

558

559

560

561

562

563

564

565

566

567

568

569

570

571

572

573

574

575

576

577

578

579

Figure 2. Change in A) weight (symbols) and thermal growth coefficient (TGC, vertical bars) for each growth period; B) feed conversion ratio (FCR) for each growth period; and C) condition factor $(\mathrm{K})$ of diploid and triploid Atlantic salmon fed a standard (SP) or nutrient boosted package (BP) diets during seawater grow out. Lower case superscripts denote significant differences between ploidy and diet.

Figure 3. A) Percentage of deformed vertebra along the vertebral column; B) Mean percentage of total deformed vertebra within each spinal region; and C) Vertebral lengthheight ratio $(\mathrm{L}: \mathrm{H})$ along the vertebral column in diploid and triploid Atlantic salmon fed a standard (SP) or nutrient boosted package (BP) diet during seawater grow out. Lower case superscripts denote significant differences between dietary treatments within region. The vertebral column has been divided into four regions as defined by Kacem et al., (1998).

Figure 4. A) Total mineral content (\% bone dry weight); B) Stiffness (N / mm), C) Yield $\operatorname{load}(\mathrm{N})$ required to crush an individual vertebra; and $\mathbf{D})$ resilience $(\mathrm{N} \times \mathrm{mm})$ as a measure of total energy required to crush a single vertebra for each of the three regions examined (R1 v68; R2/3 v28-30 and R4 v52-54) at the end of seawater grow out in diploid and triploid Atlantic salmon previously fed a standard (SP) or nutrient boosted package (BP) diet. Results are the pool of three vertebra from each region per fish analysed. Lower case superscripts denote significant differences within regions between dietary groups.

Figure 5. Final harvest data showing A) distribution of harvested fish weight classification (2N SP: $n=13,452 ; 3 n$ SP: $n=11,075 ; 3 N$ BP: $n=11854)$; and B) cause of downgrading at final processing according to Marine Harvest Quality Standards. 


\section{References}

Atkins, M.E., Benfey, T.J., 2008. Effect of acclimation temperature on routine metabolic rate in triploid salmonids. Comp. Biochem. Physiol. 149A, 157-161.

Baeverfjord, G., Asgard, T., Shearer, K.D., 1998. Development and detection of phosphorus deficiency in Atlantic salmon, Salmo salar L., parr and post-smolts. Aquac. Nutr. 4, 111.

Belghit, I., Skiba-Cassy, S., Geurden, I., Dias, K., Surget, A., Kaushik, S., Panserat, S., Seiliez. I., 2014. Dietary methionine availability affects the main factors involved in muscle protein turnover in rainbow trout (Oncorhynchus mykiss). Brit. J. Nutr. 112, 493 503.

Berg, A., Rodseth, O.M., Tangeras, A., Hansen, T., 2006. Time of vaccination influences development of adhesions, growth and spinal deformities in Atlantic salmon Salmo salar. Dis. Aquat. Org. 69, 239-248.

Bjørnevik, M., Espe, M., Beattie, C., Nortvedt, R., Kiessling, A., 2004. Temporal variation in muscle fibre area, gaping, texture, colour and collagen in triploid and diploid Atlantic salmon (Salmo salar L). J. Sci. Food Agric. 84, 530-540.

Bureau, D.P., Hua, K., Cho, C.Y., 2006. Effect of feeding level on growth and nutrient deposition in rainbow trout (Oncorhynchus mykiss) growing from 150 to $600 \mathrm{~g}$. Aquacult. Res. 37, 1090-1098.

Burke, H.A., Sacobie, C.F.B., Lall, S.P., Benfey, T.J., 2010. The effect of triploidy on juvenile Atlantic salmon (Salmo salar L.) response to varying levels of dietary phosphorus. Aquaculture, 306, 295-301.

Carter, C.G., McCarthy, I.D., Houlihan, D.F., Johnstone, R., Walsingham, M.V., Mitchell, A.I., 1994. Food consumption, feeding behaviour, and growth of triploid and diploid Atlantic salmon, Salmo salar L., parr. Can. J. Zool. 72, 609-617.

Choubert, G., Blanc J.-M., 1989. Dynamics of dietary canthaxanthin utilization in sexualiy maturing female rainbow trout (Salmo gairdneri Rich,) compared to triploids, Aquaculture, 83, 359-366.

Choubert, G., Blanc J.-M., Valle, F., 1997. Colour measurement, using the CIELCH colour space, of muscle of rainbow trout, Oncorhynchus mykiss (Walbaum), fed astaxanthin: effects of family, ploidy, sex, and location of reading. Aqua. Res. 28, 15-22. 
Cleveland, B.M., Weber, G.M., 2013. Effects of triploidy on growth and protein degradation in skeletal muscle during recovery from feed deprivation in juvenile rainbow trout (Oncorhynchus mykiss). Comp. Biochem. Physiol. A 166, 128-137.

Cleveland, B.M., Weber, G.M., 2014. Ploidy effects on genes regulating growth mechanisms during fasting and refeeding in juvenile rainbow trout (Oncorhynchus mykiss). Mol. Cell. Endocrinol. 382, 139-149.

Cleveland, B.M., Kenney, P.B., Manor, M.L., Weber, G.M., 2012. Effects of feeding level and sexual maturation on carcass and fillet characteristics and indices of protein degradation in rainbow trout (Oncorhynchus mykiss). Aqauculture, 338-341, 228-236.

Cotter, D., O'Donovan, V., Drumm, A., Roche, N., Ling, E.N.,Wilkins, N.P., 2002. Comparison of freshwater and marine performances of all female diploid and triploid Atlantic salmon (Salmo salar L.). Aquacult. Res. 33, 43-53.

Fjelldal, P.G., Hansen, T., 2010. Vertebral deformities in triploid Atlantic salmon (Salmo salar L.) underyearling smolts. Aquaculture, 309, 131-136.

Fjelldal, P.G., Grotmol, S., Kryvi, H., Gjerdet, N.R., Taranger, G.L., Hansen, T., Porter, M.J., Totland, G.K., 2004. Pinealectomy induces malformation of the spine and reduces the mechanical strength of the vertebrae in Atlantic salmon, Salmo salar. J. Pineal Res. 36, $132-139$.

Fjelldal, P.G., Lock, E.J., Grotmol, S., Totland, G.K., Nordgarden, U., Flik, G., Hansen, T., (2006) Impact of smolt production strategy on vertebral growth and mineralisation during smoltification and the early seawater phase in Atlantic salmon (Salmo salar L.). Aquaculture, 261, 715-728.

Fjelldal, P.G., Hansen, T., Breck, O., Sandvik, R., Waagbø, R., Berg, A., Ørnsrud, R., 2009. Supplementation of dietary minerals during the early seawater phase increase vertebral strength and reduce the prevalence of vertebral deformities in fast-growing underyearling Atlantic salmon (Salmo salar L.) smolt. Aquac. Nutr. 15, 366-378.

Fjelldal, P.G., Hansen, T. \& Albrektsen, S., 2012. Inadequate phosphorus nutrition in juvenile Atlantic salmon has a negative effect on long-term bone health. Aquaculture, 334, $117-$ 123.

Fjelldal, P.G., Hansen, T.J., Lock, E.-J., Wargelius, A., Fraser, T.W.K., Sambraus, F., ElMowafi, A., Albrektsen, S., Waagbø, R., Ørnsrud, R. 2015. Increased dietary phosphorous prevents vertebral deformities in triploid Atlantic salmon (Salmo salar L.). Aquac Nutr. (doi: 10.1111/anu.12238) 
Fraser, T.W.K., Fjelldal, P.G., Hansen, T., Mayer, I., 2012a.Welfare considerations of triploid fish. Rev. Fish. Sci. 20, 192-211.

647

648

649

650

651

652

653

654

655

656

657

658

659

660

661

662

663

664

665

666

667

668

669

670

671

672

673

674

675

676

Fraser, T.W.K., Rønneseth, A., Haugland, G.T., Fjelldal, P.G., Mayer, I., Wergeland, H.I., 2012b. The effect of triploidy and vaccination on neutrophils and B-cells in the peripheral blood and head kidney of $0+$ and $1+$ Atlantic salmon (Salmo salar) postsmolts. Fish Shellfish Immunol. 33, 60-66.

Fraser, T.W.K., Fleming, M.S., Poppe, T.T., Hansen, T., Fjelldal, P.G., 2013a. The effect of ploidy and incubation temperature on survival and the prevalence of aplasia of the septum transversum in Atlantic salmon, Salmo salar L J. Fish Dis. 37, 189-200.

Fraser, T.W.K., Hansen, T., Skjæraasen, J.E., Mayer, I., Sambraus, F., Fjelldal, P.G., 2013b. The effect of triploidy on the culture performance, deformity prevalence, and heart morphology in Atlantic salmon. Aquaculture 416-417, 255-264.

Fraser, T.W.K., Hansen, T., Fleming, M.S., Fjelldal, P.G., 2014a. The prevalence of vertebral deformities is increased with higher egg incubation temperatures and triploidy in Atlantic salmon Salmo salar L. J. Fish Dis. 37, 189-200.

Fraser, T.W.K., Hansen, T., Mayer, I., Skjæraasen, J.E., Glover, K.A., Sambraus, F., Fjelldal, P.G., 2014b. The effect of triploidy on vaccine side-effects in Atlantic salmon. Aquaculture 433, 481-490.

Friars, G.W., McMillan, I., Quinton, M.V., O'Flynn, F.M., McGeachy, A.S., Benfey, T.J., 2001. Family differences in relative growth of diploid and triploid Atlantic salmon (Salmo salar L.). Aquaculture 192, 23-29.

Gil-Martens, L., Fjelldal, P.G., Lock, E.-J., Wargelius, A., Wergeland, H., Witten, P.E., Hansen, T., Waagbø, R., Ørnsrud, R., 2012. Dietary phosphorus does not reduce the risk for spinal deformities in a model of adjuvant-induced inflammation in Atlantic salmon (Salmo salar) postsmolts. Aquac. Nutr. 18, 12-20.

Gjerde, B., Pante, J.R., Baeverfjord, G., 2005. Genetic variation for a vertebral deformity in Atlantic salmon (Salmo salar). Aquaculture 244, 77-87.

Hansen, T., Fjelldal, P.G., Yurtseva, A., Berg, A., 2010. A possible relation between growth and number of deformed vertebrae in Atlantic salmon (Salmo salar L.). J. Appl. Ichthyol., 26, 355-359.

Hansen, T., Olsen, R.E., Stein, L., Oppedal, F., Torgersen, T., Breck, O., Remen, M., Vågseth, T., Fjelldal, P.G., 2015. Effect of water oxygen level on performance of diploid 
and triploid Atlantic salmon post-smolts reared at high temperature. Aquaculture 435, 354-360.

Helland, S., Refstie, S., Espmark, A., Hjelde, K., Baeverfjord, G., 2005. Mineral balance and bone formation in fast-growing Atlantic salmon parr (Salmo salar L.) in response to dissolved metabolic carbon dioxide and restricted dietary phosphorus supply. Aquaculture 250, 364-376.

Houlihan, D.F., Carter, C.G., McCarthy, I.D., 1995. Protein synthesis in fish. In:Mommsen, H.A. (Ed.), Biochemistry and Molecular Biology of Fishes. Elsevier Science B.V., 191219.

Johnston, I.A., Alderson, R., Sandham, C., Dingwall, A., Mitchell, D., Selkirk, C., Nickell, D., Baker, R., Robertson, B., Whyte, D., Springate J., 2000. Muscle fibre density in relation to the colour and texture of smoked Atlantic salmon (Salmo salar L). Aquaculture 189, 335-349.

Johnston, I.A., Manthri, S. Bickerdike, R., Dingwall, A., Luijkx, R., Campbell, P., Nickell, D., Alderson, R., 2004. Growth performance, muscle structure and flesh quality in outof-season Atlantic salmon (Salmo salar) smolts reared under two different photoperiod regimes. Aquaculture 237, 281-300.

Kacem, A., Meunier, F.J., Baglinière, J.L., 1998. A quantitative study of morphological and histological changes in the skeleton of (Salmo salar) during its anadromous migration. Journal of Fish Biology 53, 1096-1109.

Lall, S.P. \& Lewis-McCrea, L.M., 2007. Role of nutrients in skeletal metabolism and pathology in fish - An overview. Aquaculture, 267, 3-19.

Leclercq, E., Taylor, J.F., Fison, D., Fjelldal, P.G., Diez-Padrisa, M., Hansen, T., Migaud, H., 2011. Comparative seawater performance and deformity prevalence in out-of-season diploid and triploid Atlantic salmon (Salmo salar) post-smolts. Comp. Biochem. Physiol. A. Mol. Integr. Physiol, 158, 116-125.

Lijalad, M., Powell, M.D., 2009. Effects of lower jaw deformity on swimming performance and recovery from exhaustive exercise in triploid and diploid Atlantic salmon, Salmo salar L. Aquaculture 290, 145-154.

McCormick, S.D., 1993. Methods for nonlethal gill biopsy and measurement of $\mathrm{Na}+\mathrm{K}+-$ ATPase activity. Can. J. Fish. Aquat. Sci. 50, 656-658.

McGinnity, P., Prodöhl, P., Ferguson, A., Hynes, R., O'Maoiléidigh, N., Baker, N., Cotter, D., O'Hea, B., Cooke, D., Rogan, G., Taggart, J., Cross, T., 2003. Fitness reduction and 
potential extinction of wild populations of Atlantic salmon, Salmo salar, as a result of interactions with escaped farm salmon. Proc. R. Soc. Lond. Ser. B Biol. Sci. 270, 24432450 .

Manor, M.L., Weber, G.M., Cleveland, B.M., Yao, J., Kenney, P.B., 2015. Expression of genes associated with fatty acid metabolism during maturation in diploid and triploid female rainbow trout. Aquaculture 435, 178-186.

Michie, I., 2001. Causes of downgrading in the salmon industry. In: Farmed Fish Quality (Kestin, S.C. \& Warris, P.D. eds), 129-136. Fishing News Books, Oxford.

NRC., 2011. Nutrient Requirements of Fish and Shrimp (National Research Council, Committee on Animal Nutrition, Board on Agriculture ed), pp. 57-102, National Academy Press, Washington, DC.

O'Flynn, F.M., McGeachy, S.A., Friars, G.W., Benfey, T.J., Bailey, J.K., 1997. Comparisons of cultured triploid and diploid Atlantic salmon (Salmo salar L.). ICES J. Mar. Sci. 54, 1160-1165.

Olivia-Teles, A., Kaushik, S.J., 1990. Growth and nutrient utilization by $0+$ and 1+triploid rainbow trout, Oncorhynchus mykiss. J. Fish Biol. 37, 125-133.

Oppedal, F., Taranger, G.L., Hansen, T., 2003. Growth performance and sexual maturation in diploid and triploid Atlantic salmon (Salmo salar L.) in seawater tanks exposed to continuous light or simulated natural photoperiod. Aquaculture 215, 145-162.

Poppe, T.T., Johansen, R., Gunnes, G., Torud, B., 2003. Heart morphology in wild and farmed Atlantic salmon Salmo salar and rainbow trout Oncorhynchus mykiss. Dis. Aquat. Organ. 57, 103-108.

Preston, A.C., Taylor, J.F., Adams, C.E., Migaud, H., 2014. Surface feeding and aggressive behaviour of diploid and triploid brown trout Salmo trutta during allopatric pair-wise matchings J. Fish Biol. 85, 882-900.

Roberts, R.J., Hardy, R.W., Sugiura, S.H., 2001. Screamer disease in Atlantic salmon, Salmo salar L., in Chile. J. Fish Dis. 24, 543-549.

Taylor, J.F., Preston, A.C., Guy, D.R., Migaud, H., 2011. Ploidy effects on hatchery survival, deformities, and performance in Atlantic salmon (Salmo salar). Aquaculture 315, 61-68.

Taylor, J.F., Leclercq, E., Preston, A.C., Guy, D.R., Migaud, H., 2012. Parr-smolt transformation in out-of-season triploid Atlantic salmon (Salmo salar L.). Aquaculture $362-363,255-263$. 
Taylor, J.F., Sambraus, F., Velasco, J.C., Guy, D., Hamilton, A., Hunter, D., Corrigan, D., Migaud, H., 2013. Ploidy and family effects on Atlantic salmon (Salmo salar) growth, deformity and harvest quality during a full commercial. Aquaculture 410-411, 41-50.

Taylor J.F., Bozzolla, P., Frenzl, B., Hunter, D., Migaud, H., 2014. Triploid Atlantic salmon growth is negatively affected by communal ploidy rearing during seawater rearing in tanks. Aquaculture. 142, 163-174.

Taylor, J.F., Waagbø, R., Diez-Padrisa, M., Campbell, P., Walton, J., Hunter, D., Matthew, C., Migaud, H., 2015. Adult triploid Atlantic salmon (Salmo salar) have higher dietary histidine requirements to prevent cataract development in seawater. Aquac. Nutr. 21, 1832.

Tiago, D.M., Laizé, V., Cancela, ML., 2008. Impairment of mineralization by metavanadate and decavanadate solutions in a fish bone-derived cell line. Cell. Biol. Toxicol. 24, 253263.

Tibbetts, S.M., Wall, C.L., Barbosa-Solomieu, V., Bryenton, M.D., Plouffe, D.A., Buchanan, J.T., Lall , S.P., 2013. Effects of combined "all-fish" growth hormone transgenics and triploidy on growth and nutrient utilization of Atlantic salmon (Salmo salar L.) fed a practical grower diet of known composition. Aquaculture 406-407, 141-152.

Totland, G.K., Fjelldal, P.G., Kryvi, H., Løkka, G., Wargelius, A., Sagstad, A., Hansen, T. \& Grotmol, S., 2011. Sustained swimming increases the mineral content and osteocyte density of salmon vertebral bone. J. Anat., 219, 490-501.

Venegas, F., Montiel, E., Forno, P., Rojas, M., 2003. Histology of the jaw deformation in salmon of southern Chile (Salmo salar). Int. J. Morphol. 21, 211-219.

Wall, A.E., Richards, R.H., 1992. Occurrence of cataracts in triploid Atlantic salmon (Salmo salar) on four farms in Scotland. Veterinary Record 131, 553-557.

Wargelius, A., Fjelldal, P.G., Hansen, T., 2005. Heat shock during early somitogenesis induces caudal vertebral column defects in Atlantic salmon (Salmo salar). Dev. Gen. Evol., 215, 350-357.

Witten, P.E., Gil-Martens, L., Huysseune, A., Takle, H., Hjelde, K., 2009. Towards a classification and an understanding of developmental relationships of vertebral body malformations in Atlantic salmon (Salmo salar L.). Aquaculture 295, 6-14.

Ytteborg, E., Torgersen, J., Pedersen, M., Baeverfjord, G., Hannesson, K., Takle, H., 2010c. Remodelling of the notochord during development of vertebral fusions in Atlantic salmon (Salmo salar). Cell Tissue Res. 342, 363-376. 
775 Ytteborg, E., Torgersen, J.S., Pedersen, M.E., Helland, S.J., Grisdale-Helland, B., Takle, H., 776 2013. Exercise induced mechano-sensing and substance P mediated bone modelling in $777 \quad$ Atlantic salmon. Bone 53, 259-268. 
Table 1. Composition (\%) of the standard nutrient diet (SP) and boosted nutrient diet (BP) fed during the experimental period.

\section{SP BP}

\begin{tabular}{lcc}
\hline Diets as formulated (\%) & 25.1 & 28.3 \\
Fish/Crustacean meal & 1.2 & 1.2 \\
Pea protein & 3.8 & 4.6 \\
Soy Protein Concentrate & 8.3 & 8.2 \\
Corn gluten & 10.0 & 5.7 \\
Sunflower expeller & 7.0 & 5.4 \\
Wheat & 7.6 & 6.6 \\
Wheat gluten & 5.8 & 7.1 \\
Dehulled beans & 13.4 & 13.9 \\
Fish oil & 14.6 & 14.9 \\
Rape oil & 3.1 & 4.2 \\
Additives* & & \\
Nutritional content & 32.8 & 32.8 \\
Oil $(\%) \dagger$ & 37.6 & 40.1 \\
Protein $(\%) \$$ & 24.8 & 24.8 \\
Energy $(\mathrm{KJ} / \mathrm{g}) \dagger$ & 0.99 & 1.20 \\
Total Phosphorus $(\%) \S$ & & \\
\hline & & \\
\hline
\end{tabular}

* BioFish premix (not commercially available) with additional Essential Amino Acids

$\uparrow$ Nutritional Analytical Service, University of Stirling, UK

† BioMar, Grangemouth, UK

$\S$ Eurofins, Denmark 
Table 2. A) Total visible external deformity ( $\%$, mean \pm SEM) observed at smolt $(n=72-92$ ploidy) and at harvest $(n=500 /$ pen $)$ for diploid $(2 \mathrm{~N})$ and triploid $(3 \mathrm{~N})$ fed the standard nutrient diet (SP) or boosted nutrient diet (BP). B) Radiological deformed vertebra (dV) and severity of affected vertebra per deformed fish at smolt $(\mathrm{n}=72-92$ ploidy) and at harvest $(\mathrm{n}=$ 20 / ploidy / diet) for fish exhibiting no externally visible signs of deformity. Lower case superscripts denote significant differences between ploidy at smolt, or between dietary treatments and ploidy at harvest.

\begin{tabular}{lcccccc}
\hline & \multicolumn{2}{c}{ Smolt } & & \multicolumn{3}{c}{ Harvest } \\
\cline { 2 - 3 } \cline { 5 - 6 } \cline { 5 - 6 } & $\mathbf{2 N}$ & $\mathbf{3 N}$ & & $\mathbf{2 N ~ S P}$ & 3N SP & 3N BP \\
\hline A.) External Visible Deformity & & & & & \\
None (\%) & $\mathrm{n} / \mathrm{a}$ & $\mathrm{n} / \mathrm{a}$ & & $97.8 \pm 0.1^{\mathrm{a}}$ & $81.0 \pm 1.3^{\mathrm{b}}$ & $79.7 \pm 2.9^{\mathrm{b}}$ \\
Jaw (\%) & $\mathrm{n} / \mathrm{a}$ & $\mathrm{n} / \mathrm{a}$ & & $0.9 \pm 0.0^{\mathrm{b}}$ & $9.7 \pm 2.3^{\mathrm{a}}$ & $11.4 \pm 2.6^{\mathrm{a}}$ \\
Vertebral (\%) & $\mathrm{n} / \mathrm{a}$ & $\mathrm{n} / \mathrm{a}$ & & $1.3 \pm 0.5^{\mathrm{b}}$ & $9.3 \pm 0.5^{\mathrm{a}}$ & $9.9 \pm 0.1^{\mathrm{a}}$ \\
B.) Radiological Vertebral Deformity & & & & \\
Ave. V No. & $59.4^{\mathrm{a}}$ & $58.4^{\mathrm{b}}$ & & $59.2 \pm 0.2^{\mathrm{a}}$ & $58.4 \pm 0.1^{\mathrm{b}}$ & $58.4 \pm 0.1^{\mathrm{b}}$ \\
Ave. no. dV & $1.9^{\mathrm{b}}$ & $5.8^{\mathrm{a}}$ & & $3.3 \pm 0.0^{\mathrm{c}}$ & $11.5 \pm 1.6^{\mathrm{a}}$ & $6.0 \pm 1.6^{\mathrm{b}}$ \\
0dV (\%) & 63.0 & 23.6 & & $60.0 \pm 0.0^{\mathrm{a}}$ & $15.0 \pm 5.0^{\mathrm{b}}$ & $15.0 \pm 5.0^{\mathrm{b}}$ \\
1-5dV (\%) & 37.0 & 43.1 & & $25.0 \pm 5.0^{\mathrm{ab}}$ & $10.0 \pm 10.0^{\mathrm{b}}$ & $45.0 \pm 5.0^{\mathrm{a}}$ \\
6-9dV (\%) & 0.0 & 19.4 & & $10.0 \pm 0.0^{\mathrm{b}}$ & $30.0 \pm 0.0^{\mathrm{a}}$ & $25.0 \pm 5.0^{\mathrm{a}}$ \\
$\geq 10 \mathrm{dV}(\%)$ & 0.0 & 13.9 & & $5.0 \pm 5.0^{\mathrm{b}}$ & $45.0 \pm 5.0^{\mathrm{a}}$ & $15.0 \pm 10.0^{\mathrm{b}}$ \\
\hline n/a: not assessed & & & & &
\end{tabular}


Table 3. Mineral content (\%) of the vertebrae for diploid (2N) and triploid (3N) fed a standard nutrient (SP) or a boosted nutrient (BP) diet. Significant differences between treatments are denoted using lower case superscripts.

\begin{tabular}{cccc}
\hline & 2N SP & 3N SP & 3N BP \\
\hline $\mathbf{C a}$ & $13 \cdot 10 \pm 0 \cdot 03^{\mathrm{a}}$ & $12 \cdot 70 \pm 0 \cdot 39^{\mathrm{ab}}$ & $12 \cdot 18 \pm 0 \cdot 0^{\mathrm{b}}$ \\
$\mathbf{P}$ & $6 \cdot 76 \pm 0 \cdot 10^{\mathrm{a}}$ & $6 \cdot 58 \pm 0 \cdot 1^{\mathrm{b}}$ & $6 \cdot 25 \pm 0 \cdot 0^{\mathrm{b}}$ \\
$\mathbf{C a}: \mathbf{P}$ & $1 \cdot 94 \pm 0 \cdot 02$ & $1.93 \pm 0.03$ & $1 \cdot 95 \pm 0 \cdot 01$ \\
$\mathbf{M g}$ & $0 \cdot 172^{\mathrm{a}} \pm 0 \cdot 001$ & $0 \cdot 169^{\mathrm{ab}} \pm 0 \cdot 003$ & $0 \cdot 160^{\mathrm{b}} \pm 0 \cdot 001$ \\
$\mathbf{V}$ & $3 \cdot 26^{*} 10^{-3} 0 \cdot 14^{\mathrm{b}}$ & $3 \cdot 13^{*} 10^{-3} \pm 0 \cdot 20^{\mathrm{b}}$ & $4 \cdot 21 * 10^{-3} \pm 0 \cdot 15^{\mathrm{a}}$ \\
$\mathbf{Z n}$ & $0 \cdot 0119 \pm 0 \cdot 001^{\mathrm{a}}$ & $0 \cdot 0118 \pm 0 \cdot 0001^{\mathrm{a}}$ & $0 \cdot 0105 \pm 0 \cdot 0001^{\mathrm{b}}$ \\
\hline
\end{tabular}


Table 4. Breakdown of harvest weight and condition factor (mean \pm SEM) into fish exhibiting no externally visible signs of deformity ( 2 N SP $n=195 ; 3 N$ SP $n=160 ; 3 N$ BP $\mathrm{n}=147$ ); Jaw; those exhibiting jaw deformity (2N SP $n=2 ; 3 N$ SP $n=21 ; 3 N$ BP $n=38$ ) and Vertebral; individuals with externally visible vertebral deformity ( $2 \mathrm{~N} \mathrm{SP} n=3 ; 3 \mathrm{~N} \mathrm{SP} n=19$; $3 \mathrm{~N}$ BP $\mathrm{n}=12$ ). Upper case superscripts denote significant differences between the three categories ('no visible deformity, 'jaw' and 'vertebral') within a given treatment, while lower case superscripts denote significant differences between treatments within each category.

\begin{tabular}{lccc}
\hline & 2N SP & 3N SP & 3N BP \\
\hline Harvest Weight $(\mathbf{g})$ & & & \\
No visible deformity & $3010 \pm 40^{\mathrm{bA}}$ & $2900 \pm 50^{\mathrm{bB}}$ & $3270 \pm 0^{\mathrm{aB}}$ \\
Jaw & $2430 \pm 90^{\mathrm{aB}}$ & $2830 \pm 270^{\mathrm{aB}}$ & $2730 \pm 0^{\mathrm{aC}}$ \\
Vertebra & $2960 \pm 0^{\mathrm{bA}}$ & $3680 \pm 130^{\mathrm{aA}}$ & $3480 \pm 30^{\mathrm{aA}}$ \\
Condition Factor $(\mathbf{K})$ & & & \\
No visible deformity & $1.42 \pm 0.01^{\mathrm{aAB}}$ & $1.32 \pm 0.02^{\mathrm{bB}}$ & $1.34 \pm 0.01^{\mathrm{bB}}$ \\
Jaw & $1.38 \pm 0.05^{\mathrm{aB}}$ & $1.37 \pm 0.07^{\mathrm{aB}}$ & $1.28 \pm 0.01^{\mathrm{aC}}$ \\
Vertebra & $1.51 \pm 0.00^{\mathrm{aA}}$ & $1.58 \pm 0.05^{\mathrm{aA}}$ & $1.51 \pm 0.02^{\mathrm{aA}}$ \\
\hline
\end{tabular}


Table 5. Harvest summary of (A) percentage grading of harvested fish classified as superior, ordinary or rebate (Fish scored according to Marine Harvest quality standards); B) fillet fat content; (C) fillet colour and total pigment; and (D) Mechanical and textural properties. Significant differences between treatments are denoted using lower case superscripts. NB: all data presented (B-C) is taken from the fish classed as showing no signs of external deformity ( $\mathrm{n}=20$ / ploidy / diet).

\begin{tabular}{lccc}
\hline & 2N SP & 3N SP & 3N BP \\
\hline A) Harvest Grade (\% Total Harvest) & & & \\
$\quad$ Superior & $95 \cdot 0 \pm 1 \cdot 2^{\mathrm{a}}$ & $80 \cdot 0 \pm 1 \cdot 7^{\mathrm{b}}$ & $83 \cdot 1 \pm 1 \cdot 3^{\mathrm{b}}$ \\
$\quad$ Ordinary & $3 \cdot 7 \pm 0 \cdot 9^{\mathrm{b}}$ & $13 \cdot 3 \pm 2 \cdot 0^{\mathrm{a}}$ & $13 \cdot 6 \pm 1 \cdot 3^{\mathrm{a}}$ \\
$\quad$ Rebate & $1 \cdot 4 \pm 0 \cdot 3^{\mathrm{c}}$ & $6 \cdot 7 \pm 0 \cdot 3^{\mathrm{a}}$ & $3 \cdot 3 \pm 0 \cdot 0^{\mathrm{b}}$ \\
B) Fat Analysis (\%) & & & \\
NQC Fat & $11 \cdot 61 \pm 0 \cdot 43$ & $11.72 \pm 0 \cdot 06$ & $11 \cdot 84 \pm 0 \cdot 77$ \\
Calculated SQC Fat & $19 \cdot 84 \pm 0 \cdot 68$ & $20 \cdot 15 \pm 0 \cdot 73$ & $19 \cdot 35 \pm 0 \cdot 20$ \\
DHA & $0 \cdot 93 \pm 0 \cdot 02$ & $0 \cdot 90 \pm 0 \cdot 01$ & $1 \cdot 04 \pm 0 \cdot 06$ \\
EPA & $0.63 \pm 0 \cdot 01^{\mathrm{ab}}$ & $0 \cdot 68 \pm 0 \cdot 02^{\mathrm{a}}$ & $0.60 \pm 0 \cdot 01^{\mathrm{b}}$ \\
Ratio n-3:n-6 & $1 \cdot 93 \pm 0 \cdot 02$ & $2 \cdot 00 \pm 0 \cdot 03$ & $2 \cdot 03 \pm 0 \cdot 17$ \\
C) Fillet Colour & & & \\
Pigment (mg/kg) & $5 \cdot 87 \pm 0 \cdot 24^{\mathrm{a}}$ & $5 \cdot 11 \pm 0 \cdot 07^{\mathrm{b}}$ & $4 \cdot 81 \pm 0 \cdot 09^{\mathrm{b}}$ \\
Roche Average & $26 \cdot 60 \pm 0 \cdot 25$ & $26 \cdot 25 \pm 0 \cdot 38$ & $25 \cdot 92 \pm 0 \cdot 01$ \\
D) Fillet Texture and Mechanical Properties & & $17.08 \pm 0 \cdot 23$ \\
Texture & $2 \cdot 95 \pm 0 \cdot 15$ & $3 \cdot 05 \pm 0 \cdot 10$ & $3 \cdot 13 \pm 0 \cdot 18$ \\
Gaping & $1 \cdot 30 \pm 0 \cdot 10$ & $1 \cdot 05 \pm 0 \cdot 10$ & $1 \cdot 28 \pm 0 \cdot 08$ \\
Cutting Force (N) & $17 \cdot 63 \pm 0 \cdot 76$ & $17 \cdot 98 \pm 0 \cdot 82$ & $17.6 \pm 1 \cdot 6$ \\
Total Work (mJ) & $160 \cdot 5 \pm 5 \cdot 6$ & $166 \cdot 6 \pm 8 \cdot 0$ & $159 \cdot 6$ \\
\hline
\end{tabular}


Figure 1

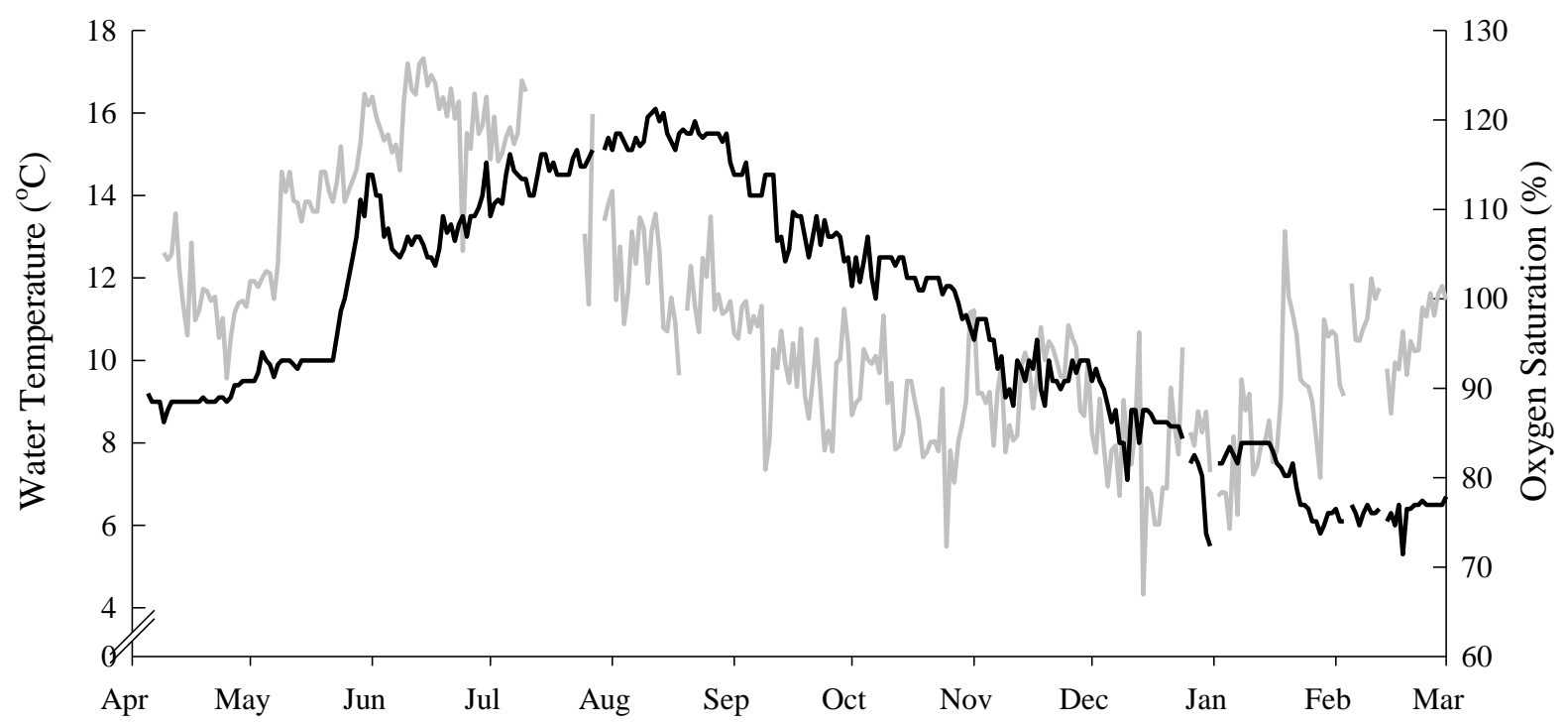

Figure 1. 
Figure 2
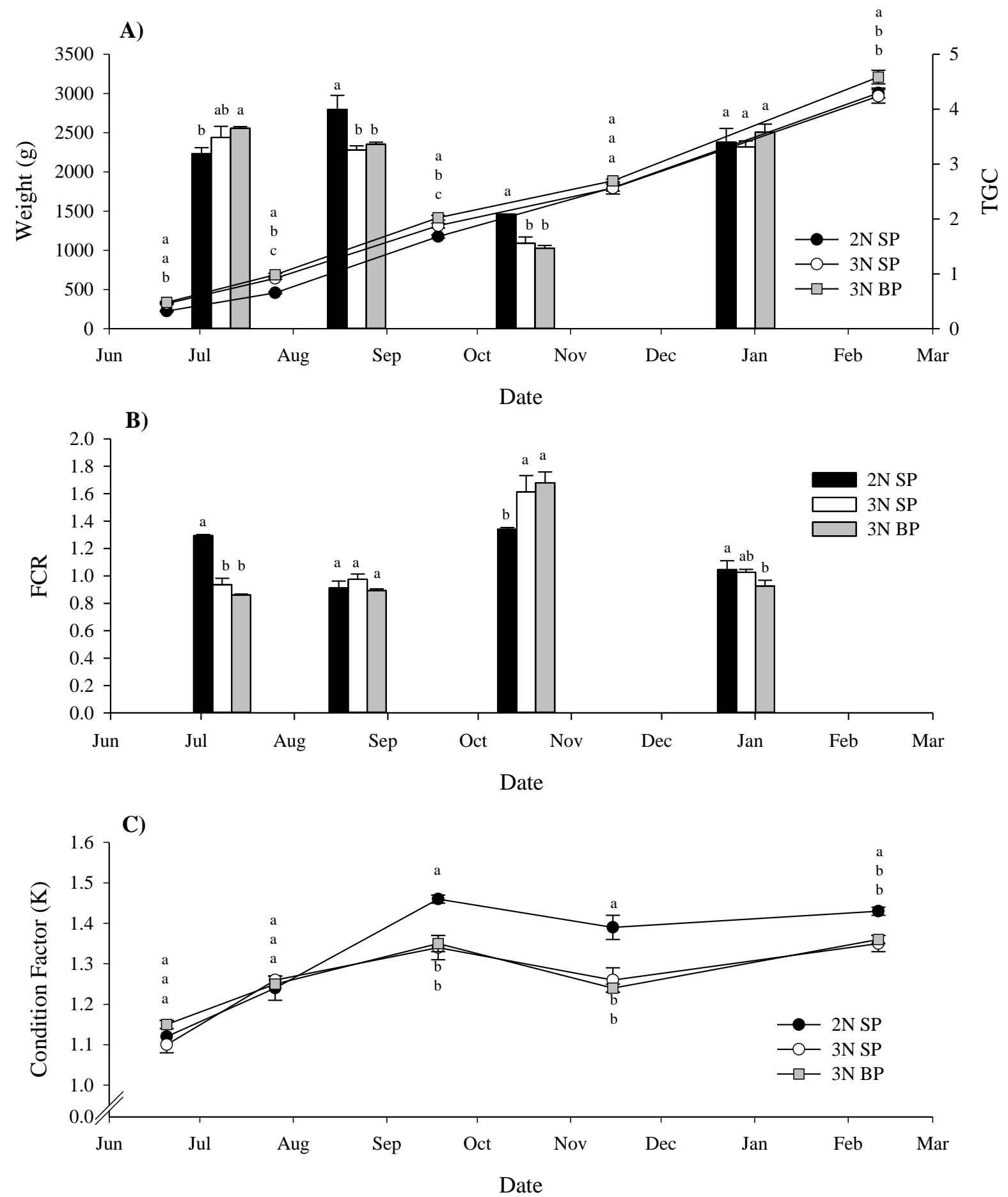

Figure 2. 

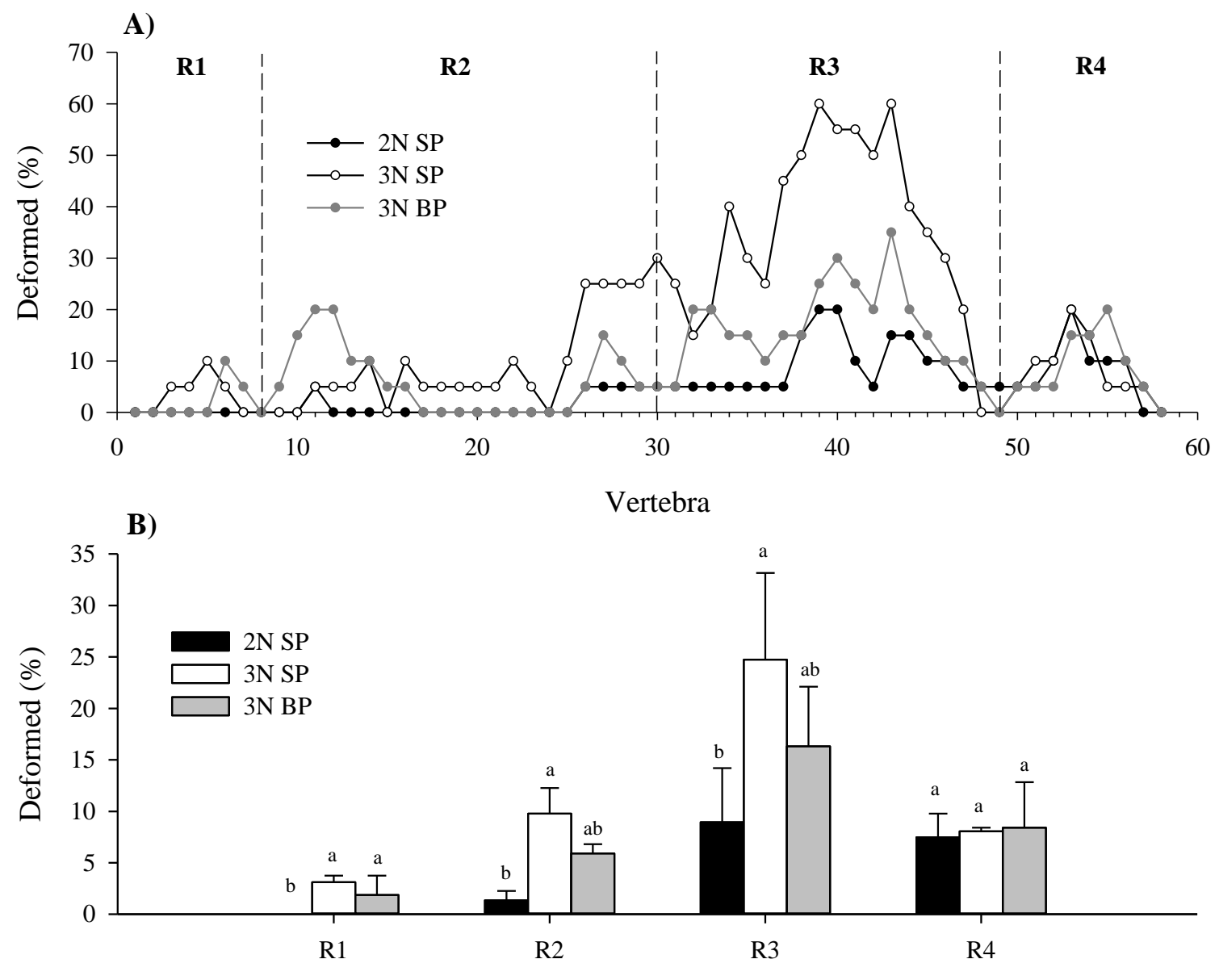

C)

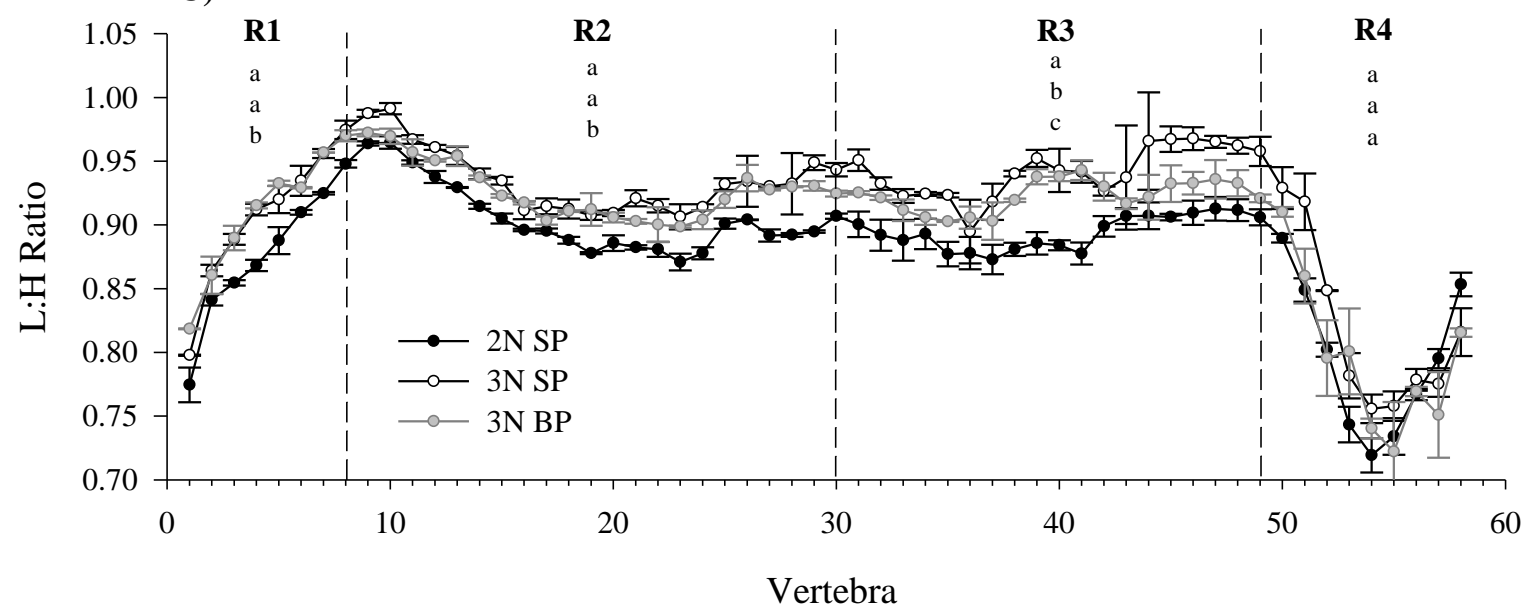

Figure 3. 
Figure 4
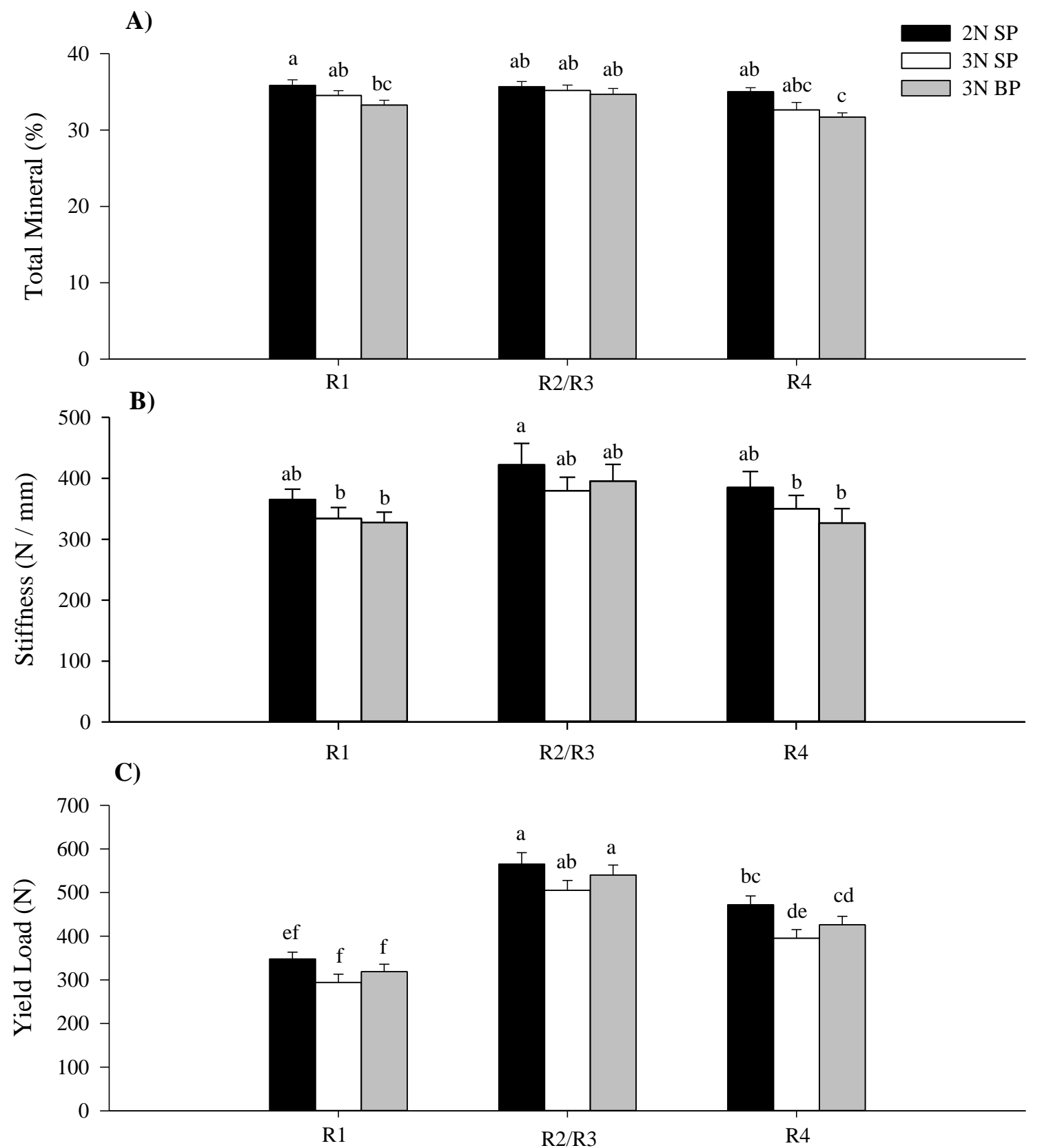

D)

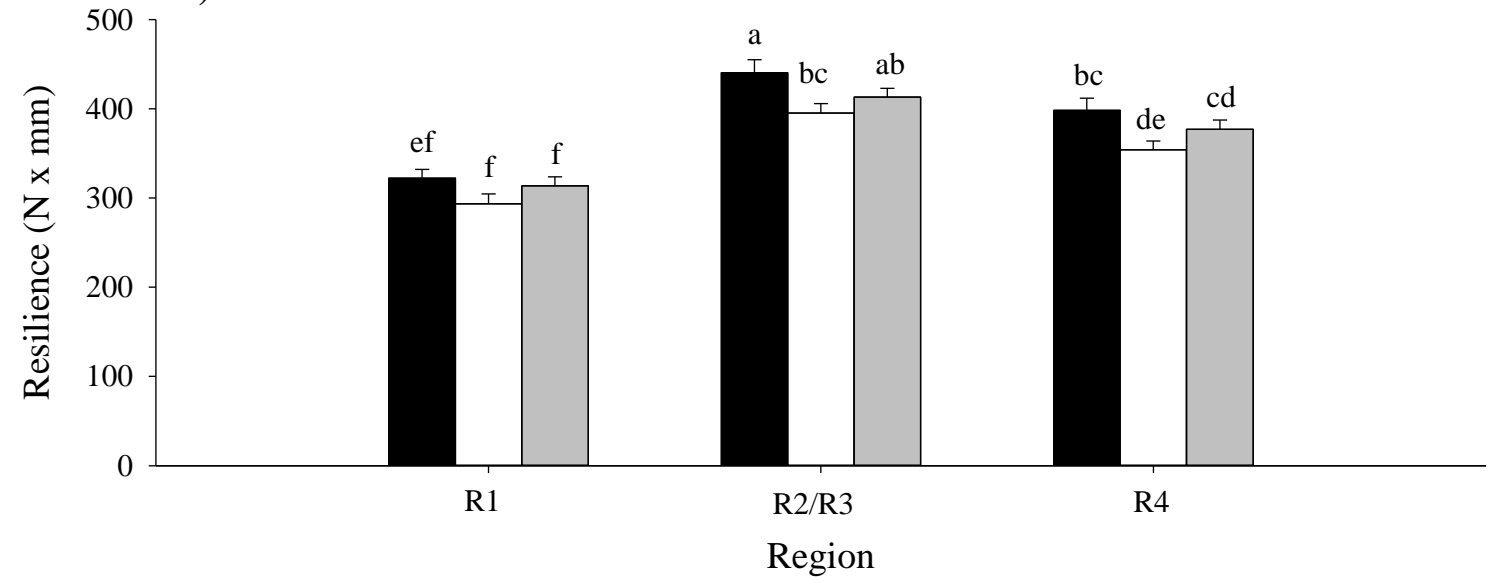

Figure 4. 
Figure 5

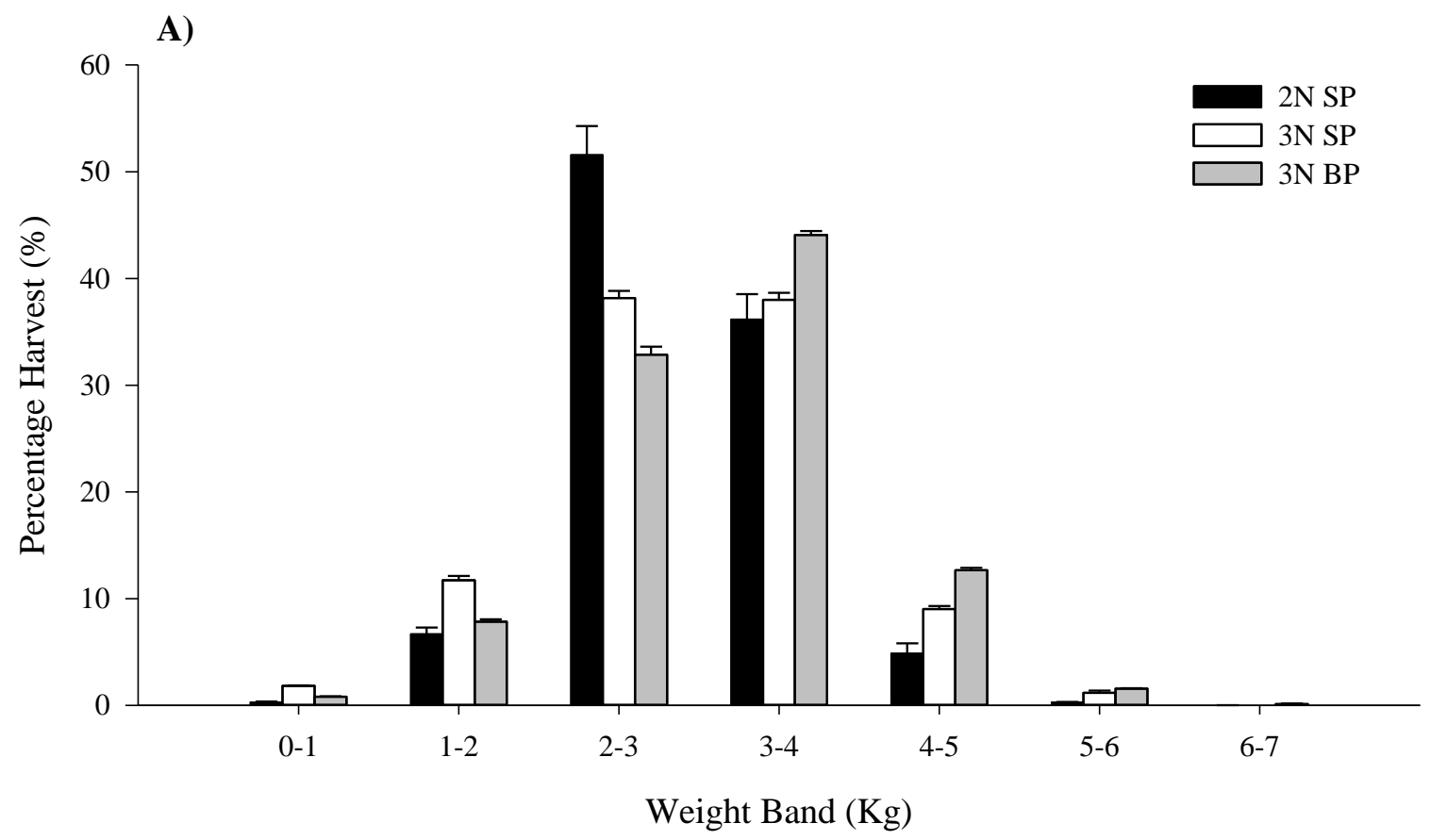

B)

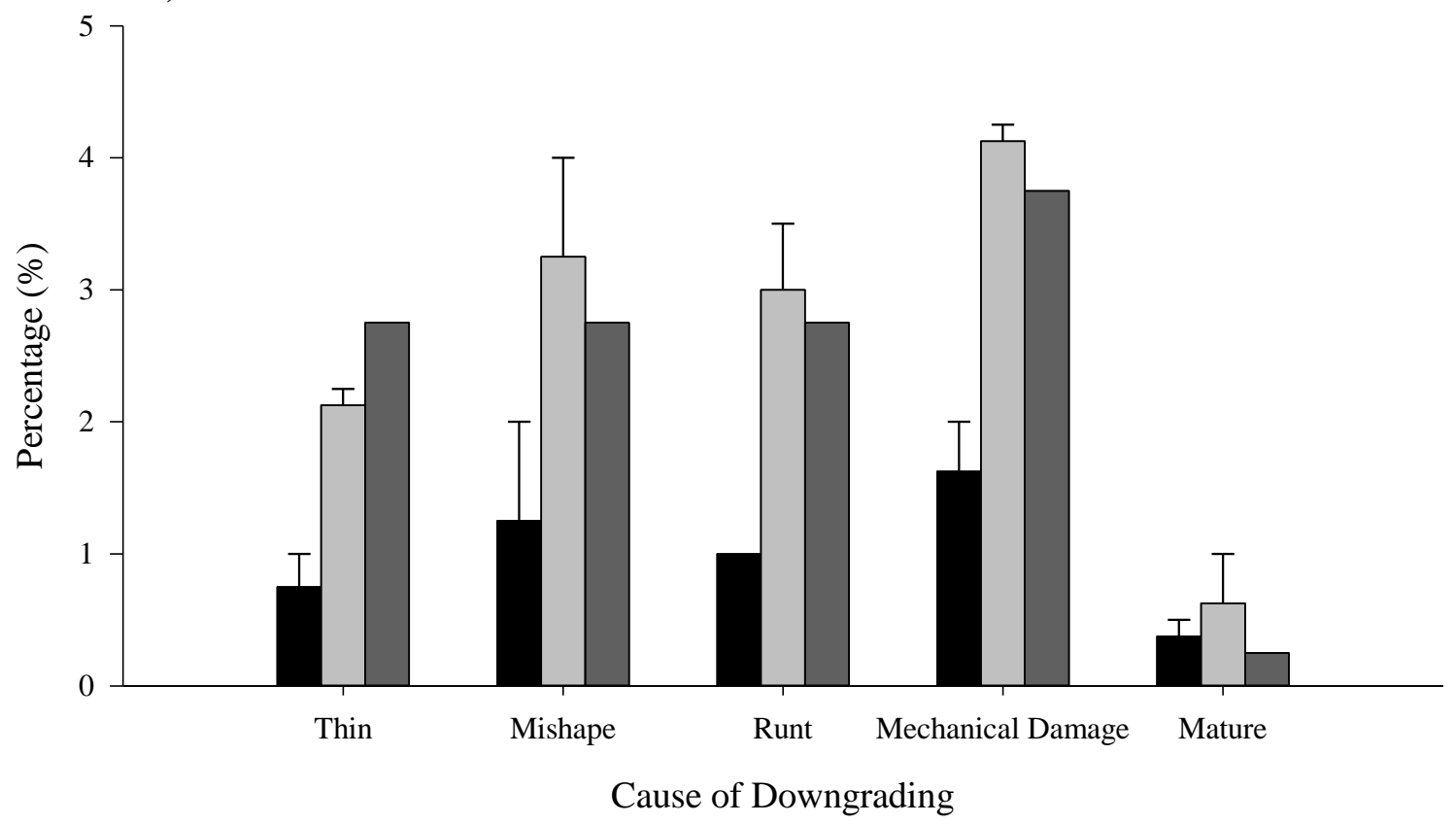

Figure 5. 